Article

\title{
Blueberry Consumption Challenges Hepatic Mitochondrial Bioenergetics and Elicits Transcriptomics Reprogramming in Healthy Wistar Rats
}

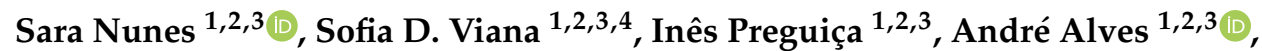

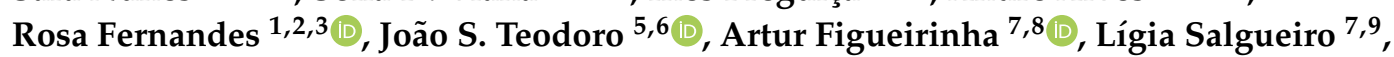
Sara Silva ${ }^{10}$, Ivana Jarak ${ }^{11}$, Rui A. Carvalho ${ }^{5,12}$, Cláudia Cavadas ${ }^{2,3,6,7}$, Anabela P. Rolo ${ }^{5,6}$, Carlos M. Palmeira ${ }^{5,6}$, Maria M. Pintado ${ }^{10}$ and Flávio Reis ${ }^{1,2,3, *(1)}$

1 Institute of Pharmacology \& Experimental Therapeutics \& Coimbra Institute for Clinical and Biomedical Research (iCBR), Faculty of Medicine, University of Coimbra, 3000-548 Coimbra, Portugal; sara_nunes20@hotmail.com (S.N.); sofia_viana@estescoimbra.pt (S.D.V.); i.preguica@campus.fct.unl.pt (I.P.); alves.andrefb@gmail.com (A.A.); rcfernandes@fmed.uc.pt (R.F.)

2 Center for Innovative Biomedicine and Biotechnology (CIBB), University of Coimbra, 3004-504 Coimbra, Portugal; ccavadas@uc.pt

3 Clinical Academic Center of Coimbra (CACC), 3004-504 Coimbra, Portugal

4 Polytechnic Institute of Coimbra, ESTESC-Coimbra Health School, Pharmacy/Biomedical Laboratory Sciences, 3046-854 Coimbra, Portugal

5 Department of Life Sciences, Faculty of Science and Technology (FCTUC), University of Coimbra, 3000-456 Coimbra, Portugal; jteodoro@ci.uc.pt (J.S.T.); rac@uc.pt (R.A.C.); anpiro@ci.uc.pt (A.P.R.); palmeira@uc.pt (C.M.P.)

6 Center for Neurosciences and Cell Biology of Coimbra (CNC), University of Coimbra, 3004-504 Coimbra, Portugal

7 Faculty of Pharmacy, University of Coimbra, 3000-548 Coimbra, Portugal; amfigueirinha@ff.uc.pt (A.F.); ligia@ff.uc.pt (L.S.)

8 LAQV, REQUIMTE, Faculty of Pharmacy, University of Coimbra, 3000-456 Coimbra, Portugal

9 CIEPQPF, Chemical Process Engineering and Forest Products Research Centre, University of Coimbra, 3000-456 Coimbra, Portugal

10 CBQF-Centro de Biotecnologia e Química Fina-Laboratório Associado, Universidade Católica Portuguesa, Escola Superior de Biotecnologia, Rua Diogo Botelho 1327, 4169-005 Porto, Portugal; snsilva@porto.ucp.pt (S.S.); mpintado@porto.ucp.pt (M.M.P.)

11 Department of Microscopy, Laboratory of Cell Biology and Unit for Multidisciplinary Research in Biomedicine (UMIB), Institute of Biomedical Sciences Abel Salazar (ICBAS), University of Porto, 4050-313 Porto, Portugal; jarak.ivana@gmail.com

12 Associated Laboratory for Green Chemistry-Clean Technologies and Processes, REQUIMTE, Faculty of Sciences and Technology, University of Porto, 4050-313 Porto, Portugal

* Correspondence: freis@fmed.uc.pt; Tel.: +351-239-480-053

Received: 22 September 2020; Accepted: 11 November 2020; Published: 14 November 2020

Abstract: An emergent trend of blueberries' (BB) "prophylactic" consumption, due to their phytochemicals' richness and well-known health-promoting claims, is widely scaled-up. However, the benefits arising from BB indiscriminate intake remains puzzling based on incongruent preclinical and human data. To provide a more in-depth elucidation and support towards a healthier and safer consumption, we conducted a translation-minded experimental study in healthy Wistar rats that consumed BB in a juice form ( $25 \mathrm{~g} / \mathrm{kg}$ body weight (BW)/day; 14 weeks' protocol). Particular attention was paid to the physiological adaptations succeeding in the gut and liver tissues regarding the acknowledged BB-induced metabolic benefits. Systemically, BB boosted serum antioxidant activity and repressed the circulating levels of 3-hydroxybutyrate (3-HB) ketone bodies and 3-HB/acetoacetate 
ratio. Moreover, BB elicited increased fecal succinic acid levels without major changes on gut microbiota (GM) composition and gut ultra-structural organization. Remarkably, an accentuated hepatic mitochondrial bioenergetic challenge, ensuing metabolic transcriptomic reprogramming along with a concerted anti-inflammatory pre-conditioning, was clearly detected upon long-term consumption of BB phytochemicals. Altogether, the results disclosed herein portray a quiescent mitochondrial-related metabolomics and hint for a unified adaptive response to this nutritional challenge. The beneficial or noxious consequences arising from this dietary trend should be carefully interpreted and necessarily claims future research.

Keywords: blueberries; long-term consumption; bioenergetics remodeling; transcriptomics reprogramming; anti-inflammatory pre-conditioning

\section{Introduction}

The continuous rise in life expectancy observed in the last decades encloses an ascending trajectory of non-communicable diseases (NCDs), which are often linked with unhealthy dietary patterns [1,2]. Society is progressively becoming more aware of healthy eating to prevent diet-related chronic diseases. New trends in food consumption have fostered agro-food and pharmaceutical companies to develop new products, both wellness-focused diets, functional foods, and oral nutraceutical supplements, to meet consumer demands [3]. A good example of this reality is blueberry (BB) market globalization, whose per capita consumption nearly tripled in USA since 2002 and is fast-expanding worldwide [4,5].

The low caloric content of BB $(0.046 \mathrm{kcal} / \mathrm{g}$ fresh fruit) pair with their enriched nutritional and phytochemical composition [6]. BB is a privileged source of micronutrients (e.g., selenium, zinc, iron), dietary prebiotic fibers (3-3.5\% of their fruit weight), and antioxidant polyphenols encompassing anthocyanins, flavonols, phenolic acids, procyanidins, and/or stilbenes derivatives, with an overall content reaching up to $0.3 \%$ of fresh fruit weight [6,7]. These bioactive compounds are extensively metabolized by the colonic microbiota; in addition, regardless of their poor oral bioavailability [8-10], BB-derived phytochemicals can positively modulate chief endogenous functions in distinct organs and tissues that extend beyond their well-documented antioxidant properties [11-14]. In fact, experimental data arising from cell-free systems, standard cell-cultures, and/or isolated organelles highlight BB phytochemicals' ability to modulate non-redox mechanisms through their interactions with functionally diverse cellular targets, such as intercalation with DNA, transcription of several genes associated with key cellular functions, mitochondria dynamics, and even gut microbiota (GM) homeostasis [4,15-18]. Convergent results are also reported in preclinical animal studies that emphasize BB consumption benefits in a panoply of chronic disorders paralleling obesity-related metabolic diseases such as cardiovascular disease (CVD), metabolic syndrome (MS) or type 2 diabetes mellitus (T2DM) [13,19-25]. Interestingly, the association between human BB consumption and biomarker-based evidence of reduced risk of diseases has been also emphasized [13,26-30]. In fact, several clinical trials have progressively emphasized on potential health benefits (e.g., endothelial, gastrointestinal, cardio-metabolic outcomes) arising from long-term BB-enriched human dietary patterns and commercially available BB supplements with the ultimate goal to empower overall health status [31-35]. Regardless of this wealth of evidence, incongruent preclinical and human data still remain an open debate and the translation into the clinical practice remains puzzling, mainly due to critical flaws surrounding studies' reproducibility [29,30,34,36,37]. For instance, in vitro assays often employ high-concentrations of BB-derived phytochemicals that are unlikely to reach systemic circulation once orally ingested in living organisms [38]. Besides dose, the compounds' bioactivity is often dependent on (i) how an organism is exposed to, (ii) for how long, and (iii) interindividual variability. The heterogeneity surrounding BB-derived phytochemicals' intake regarding the presentation forms (e.g., fresh/frozen/freeze-dried fruit, distinct cultivars, the range 
of commercially available supplementation forms) and regimen durations (e.g., short- versus long-term) actually convolutes the interpretation of contemporary preclinical and human data. Moreover, the high interindividual human variability is also well-recognized in terms of BB phytochemicals' bioavailability and bioactivity, which is largely dependent of the individual gut microbiome $[3,26,29,34,39]$. Thus, it is currently challenging to judge the benefits and/or hazardous consequences underlying this nutraceutical contemporary trend, which necessarily calls for further research.

To this end, we conducted a translation-minded experimental design in young adult healthy Wistar rats who were daily supplemented with a dose of $25 \mathrm{~g} / \mathrm{kg}$ of whole fresh BB, mirroring recent clinical trials [34,39-41] in a long-term regimen (14 weeks) [42]. Particular attention was paid to the physiological adaptations ensuing in the gut and liver tissues regarding their well-known metabolic chief functions.

\section{Materials and Methods}

\subsection{Preparation of Blueberry Juice}

Blueberries (Vaccinium corymbosum L., cultivar "Liberty") were provided from the same variety and in the same maturation stage by COAPE (Farming Cooperative of Mangualde, Mangualde, Portugal) and stored at $-80{ }^{\circ} \mathrm{C}$ until processing. To ensure that whole parts of BB fruits (peel, pulp, and seeds) were consumed, the BB were weighed, blended with drinking water, and transformed into BB juice (BJ). The amount of drinking water added was adjusted to ensure that $25 \mathrm{~g}$ of BB (per kg of rat's BW) were daily consumed. This BB dose was based on previous preclinical and human studies [34,40,43], and is equivalent to a daily consumption of $240 \mathrm{~g}$ of fresh whole BB (approximately $3 / 2$ daily cups of $\mathrm{BB})$, established taking into account the surface area of a person weighing $\approx 60 \mathrm{~kg}[40,44]$. Since whole BB juice loses about $83 \%$ of its anthocyanins content and about $40 \%$ of its antioxidant activity during storage at $4-8{ }^{\circ} \mathrm{C}$ for 10 days, BJ was freshly prepared on a daily basis [45].

\subsection{Phytochemical Analyses of Phenolic Compounds in Blueberry Juice}

A sample of fresh BJ was concentrated under reduced pressure and freeze-dried for phytochemical analysis. The lyophilized juice was dissolved in water $(7 \mathrm{mg} / \mathrm{mL})$ and injected $(100 \mu \mathrm{L})$ in a High performance liquid chromatography (HPLC) (Gilson, Middleton, WI, USA) hyphenated with a photodiode array detector PDA (model 170) and a control and processing software (Unipoint ${ }^{\circledR} 2.10$ ). The chromatograph was equipped with an auto sampler (234 autoinjector), two pumps (models 305 and 306), a manometric module (model 805), a mixer (Model 811 B), and an C18 analytical column (Spherisorb Waters ${ }^{\circledR}$ S5 ODS2; $250 \times 4.6 \mathrm{~mm}, 5 \mu \mathrm{m}$ particle size), maintained at $35{ }^{\circ} \mathrm{C}$, preceded by a guard column KS 30/4 Nucleosil 120-5 C-18, Macherey-Nagel (Duren, Germany). A mixture of 5\% aqueous formic acid solution (A) and methanol (B) was used as mobile phase, with gradient elution of $0-75 \mathrm{~min}(0-100 \% \mathrm{~B})$ at a flow rate of $1 \mathrm{~mL} / \mathrm{min}$. The UV-vis spectra were obtained between 200 and $600 \mathrm{~nm}$.

\subsection{Animals and Experimental Design}

Male Wistar rats (16-weeks-old) were purchased from Charles River Laboratories (Barcelona, Spain) and housed two per cage in ventilated cages, with controlled environmental conditions $\left(22 \pm 1^{\circ} \mathrm{C}\right.$, relative humidity of 50-60\% and a $12 \mathrm{~h}$ light-dark cycle) and ad libitum access to standard rodent chow and tap water. After one week of acclimatization period, rats were randomly assigned into two groups ( $n=8$ per group): (i) Control group (CTRL), maintained with standard rat chow containing $8.6 \% \mathrm{kcal}$ from fat (4RF21, Mucedola ${ }^{\circledR}$, Milan, Italy) and tap water and (ii) Blueberry juice group (BJ), fed the same standard chow and supplemented daily, during the experimental period of 14 weeks, with $25 \mathrm{~g} / \mathrm{kg}$ body weight (BW)/day of BJ. Following the daily dose of BJ intake, drinking water was provided ad libitum. 
The experiment was carried out in strict compliance with the National and European Communities Council Directives of Animal Care and with the ARRIVE guidelines for reporting animal research [46]. The animal's protocol was approved by the local (iCBR) Animal Welfare Body (ORBEA, \#9/2018, 30 October 2018).

Feed and beverage were provided ad libitum, with exception of the fasting periods. Beverage volume were BW was monitored weekly; food and beverage consumption were daily recorded per cage throughout the experimental protocol. Energy intake per week was calculated for each animal by using the former measurements.

\subsection{Glucose Tolerance Test (GTT) and Insulin Tolerance Test (ITT)}

During the first days of weeks 13 and 14, GTT and ITT were performed to assess the rats' ability to tolerate a glucose load and to evaluate peripheral insulin sensitivity, respectively, as previously described [47]. For the GTT, after $6 \mathrm{~h}$ of fasting period (between 8:00 a.m. and 2:00 p.m.), conscious rats were intraperitoneally (i.p.) injected with a glucose solution of $2 \mathrm{~g} / \mathrm{kg} B W$ and blood glucose (BG) levels were measured from the tail blood, recorded immediately before ( $0 \mathrm{~min})$ and 30, 60, and $120 \mathrm{~min}$ after injection, using a portable glucometer (ACCU-CHEK ${ }^{\circledR}$ Aviva, Roche Diagnostics, Mannheim, Germany). Additionally, blood samples $(\approx 30 \mu \mathrm{L})$ were collected before glucose challenge to determine the fasting insulin concentration.

For the ITT, animals were fasted during $6 \mathrm{~h}$ and injected i.p. with insulin solution $(0.75 \mathrm{units} / \mathrm{kg}$ BW; Actrapid Novo Nordisk, Bagsvaerd, Denmark). Blood glucose levels were measured in the tail vein blood collected immediately before ( $0 \mathrm{~min}$ ) and $15,30,45,60$, and $120 \mathrm{~min}$ after injection, using the glucometer (ACCU-CHEK ${ }^{\circledR}$ Aviva, Roche Diagnostics, Mannheim, Germany). The rate constant for glucose clearance (KITT) was calculated using the formula $0.693 / t_{1 / 2}$ where $t_{1 / 2}$ represents the half-life of plasma glucose decay. The plasma glucose $t_{1 / 2}$ was calculated from the slope of the least squares analysis of the glycemic concentration during the linear phase of decay [48].

The area under the curve (AUC) of GTT $\left(\mathrm{AUC}_{\mathrm{GTT}}\right)$ and of ITT $\left(\mathrm{AUC}_{\mathrm{ITT}}\right)$ were calculated using the trapezoidal method [49].

\subsection{Collection of Biological Samples}

At the end of the 14-week protocol, animals were euthanized with isoflurane overdose followed by cervical dislocation. Blood samples were immediately collected by venipuncture from the jugular vein and serum was obtained by centrifugation $\left(3000 \times g\right.$ for $15 \mathrm{~min}$ at $\left.4{ }^{\circ} \mathrm{C}\right)$ and immediately stored at $-20^{\circ} \mathrm{C}$ until processing for biochemical analysis. The liver and small portions of gastrointestinal tissues (duodenum and colon) were immediately excised, dissected, and stored in conditions according to the assay's technical requirements. The liver was firstly weighed and then divided into four distinct portions: a first piece was immediately used for functional mitochondria assays; the other two parts, reserved for protein and RNA extraction purposes, were directly frozen in liquid nitrogen and stored at $-80{ }^{\circ} \mathrm{C}$ until analysis; and a fourth piece was kept in a $10 \%$ neutral buffered formalin solution to be used for histological analysis. The relative liver weight was calculated as the ratio of absolute tissue weight $(\mathrm{g})$ to BW $(\mathrm{kg})$. During the last week of experimental protocol, 24-h urine and fecal samples were collected using metabolic cages. During this period, rats had free access to water and food. The volume of urine was recorded; feces were weighed, and samples were stored at $-80^{\circ} \mathrm{C}$ for later analysis.

\subsection{Measurement of Serum Metabolic Parameters}

Serum samples were used to perform the following measurements, through automatic validated methods and equipment (Hitachi 717 analyzer, Roche Diagnostics GMBH, Mannheim, Germany), as previously described [50]: postprandial glucose, triglycerides (TGs), total-cholesterol (Total-C), low-density lipoprotein cholesterol (LDL-C), and high-density lipoprotein cholesterol (HDL-C) levels, as well as serum glutamic-oxaloacetic (GOT) and glutamic-pyruvic (GPT) transaminases concentrations. 
Hemoglobin A1c (HbA1c) levels were determined using the DCA 2000+ analyzer (Bayer Diagnostics, Barcelona, Spain), according to the manufacturer' instructions. Serum insulin levels were determined by Enzyme-Linked ImmunoSorbent Assay (ELISA) using commercially available kits for rat samples from Mercodia (Uppsala, Sweden). Insulin resistance was evaluated by the homeostatic model assessment of insulin resistance (HOMA-IR) index, which was calculated as previously described [51], using the following formula: HOMA-IR index $=[$ fasting glucose $(\mathrm{mmol} / \mathrm{L}) \times$ fasting insulin $(\mu \mathrm{U} / \mathrm{L})] / 22.5$. High-sensitivity C-reactive protein (hs-CRP) was assayed by using a rat-specific Elisa kit (MBS764381 from Mybiosource, San Diego, CA, USA) according to the manufacturer' instructions.

\subsection{Determination of Serum Total Antioxidant Status (TAS)}

For determination of the serum TAS, ferric reducing antioxidant potential (FRAP) was performed as previously described [52], whereas the scavenging of 2,2'-Azino-bis(3-ethylbenzothiazoline-6-sulfonic acid) radical cation $\left(\mathrm{ABTS}^{\bullet+}\right.$ ) assay was employed as described by Gião et al. [53].

The $\mathrm{ABTS}^{\bullet+}$ stock solution was prepared by reacting equal amount of $7 \mathrm{mM}$ ABTS diammonium salt (Sigma-Aldrich, St. Louis, MO, USA) and $2.45 \mathrm{mM}$ potassium persulphate (Merck, Damstadt, Germany). The reaction was developed for $16 \mathrm{~h}$ in the dark. Aliquots of serum samples $(10 \mu \mathrm{L})$, diluted when needed, were added to $1 \mathrm{~mL}$ of $\mathrm{ABTS}^{\bullet+}$ solution with an initial optical density (OD) of $0.70 \pm 0.02$ measured at $734 \mathrm{~nm}$. After allowing the reaction to occur, the OD was recorded using an UV-Vis spectrophotometer (UVmini 1240, Shimadzu, Japan) and the results were calculated as inhibition percentage (IP) of $\mathrm{ABTS}^{\bullet+}$, according to the equation $\mathrm{ABTS}^{\bullet+}$ inhibition $(\%)=100-[(\mathrm{OD}$ sample $\times \mathrm{DF}) / \mathrm{OD}$ ABTS] $\times 100$, where OD sample indicates the sample absorbance following 6 min of reaction, DF is the dilution factor and OD ABTS refers to the initial absorbance of the diluted ABTS ${ }^{\bullet+}$ solution. All measurements were performed in triplicate.

\subsection{H Nuclar Magnetic Resonsance (NMR) Spectroscopy}

Before NMR analysis, $180 \mu \mathrm{L}$ of the serum samples were mixed with $45 \mu \mathrm{L}$ of a phosphate buffered $(0.2 \mathrm{M})$ sodium fumarate $(10 \mathrm{mM})$ solution $\left(99.9 \%{ }^{2} \mathrm{D}_{2} \mathrm{O}\right)$ that was used as internal standard (Sigma-Aldrich, St. Louis, MO, USA) and each sample was loaded into $3 \mathrm{~mm}$ NMR grade tubes for high resolution ${ }^{1} \mathrm{H}$ NMR analysis.

NMR spectra were obtained with a $600 \mathrm{MHz}(14.1 \mathrm{~T})$ spectrometer (Agilent, Santa Clara, CA, USA) equipped with a $3 \mathrm{~mm}$ indirect detection probe with a z-gradient. $1 \mathrm{D}-{ }^{1} \mathrm{H} \mathrm{cpmg}$ (Carr-Purcell-Meiboom-Gill spin-echo pulse sequence) experiments with water pre-saturation were acquired $(7.2 \mathrm{kHz}$ spectral width, $0.1 \mathrm{~s}$ mixing time, $4 \mathrm{~s}$ relaxation delay with $3 \mathrm{~s}$ of water pre-saturation, $90^{\circ}$ pulse angle, $3 \mathrm{~s}$ acquisition time and 128 scans at $298 \mathrm{~K}$ ). Pulse durations and water saturation frequencies were optimized for each sample. Spectra were processed by applying exponential line broadening $(0.3 \mathrm{~Hz})$, zero-filling to $64 \mathrm{k}$, and manual phasing and baseline correction. Chemical shifts were internally referenced to fumarate (singlet at $6.50 \mathrm{ppm}$ ).

Spectral assignments were based on matching the recorded spectra to the reference data available in public databases such as Human Metabolome Database (HMDM) [54]. 2D homonuclear total correlation spectroscopy (TOCSY) spectra were recorded for selected samples to help spectral assignment [55]. All metabolites were identified according to Metabolomics Standards Initiative (MSI) guidelines for metabolite identification [56] and the levels of identification are indicated in Supplementary Materials Table S1.

Processed 1D cpmg spectra were bucketed using one-point bucket (0.6-9.0 ppm, with signal-free, water, and fumarate regions excluded) using Amix Viewer (version 3.9.15, Bruker Biospin GmbH, Rheinstetten, Germany) and aligned using icoshift algorithm [57]. Resulting matrix was normalized by total spectral area included in the analysis. Multivariate statistical analysis was applied on unit variance scaled matrix (SIMCA 14, Umetrics, Sartorius Stedim Biotech, Gottingen, Germany). In order to identify clustering trends or outliers, principal component analysis (PCA) was used to provide the information on global data structure, and partial least square discriminant analysis (PLS-DA) was used 
to assess class separation and identify the main metabolites that contribute to the class discrimination. A 7-fold internal cross-validation of the PLS-DA model was used to provide the qualitative measure of predictive power (Q2) and to assess the degree of fit to the data (R2). Permutation test $(n=100)$ was also used to validate the PLS-DA model [58]. The corresponding PLS-DA loadings plot was obtained by multiplying the loading weight factors $(\mathrm{w})$ by the standard deviation of the respective variable and was color-coded according to variable importance in the projection (VIP). Selected signals of chosen metabolites (VIP > 1) were integrated in normalization by ${ }^{1} \mathrm{H}-\mathrm{NMR}$ spectra for quantitative assessment of metabolite variations between the groups.

Outliers were excluded based on the quality of the recorded NMR spectra according to the recommendations of MSI [56]. The difference between the means of the two groups was assessed using the $t$ test (results reported at a confidence level of $95 \%$ ).

\subsection{Evaluation of Serum Lipopolysaccharides (LPS) Concentration}

Serum endotoxin LPS concentration was quantified using a Pyrochrome Lisate Mix, a quantitative chromogenic reagent, diluted in glucashield buffer, which inhibits cross-reactivity with $(1 \rightarrow$ 3)- $\beta$-D-glucans (Associate of Cape Cod Incorporated, East Falmouth, MA, USA). Briefly, serum samples were diluted (1:10) in pyrogen-free water (LAL reagent water, W50-100, Lonza, Walkersville, $\mathrm{MD}, \mathrm{USA}$ ) and heated for $10 \mathrm{~min}$ at $70^{\circ} \mathrm{C}$. Samples and pyrochrome reagent (1:1) were incubated at $37^{\circ} \mathrm{C}$ for $30 \mathrm{~min}$ and absorbance was read at $405 \mathrm{~nm}$.

\subsection{Extraction and Quantification of Gut Microbiota in Feces}

\subsubsection{DNA Extraction from Stool}

Genomic DNA was extracted and purified from fecal samples using the NZY Tissue gDNA Isolation Kit (NZYtech, Lisbon, Portugal) according to the manufacturer's protocol with slight modifications [59]. Briefly, fecal samples (170 to $200 \mathrm{mg}$ ) were homogenized in Tris-EDTA buffer solution (10 mM Tris/HCl; 1 mM EDTA, pH 8.0) and centrifuged at $4000 \times g$ for $15 \mathrm{~min}$. The supernatant was discarded, and the pellet was resuspended in $350 \mu \mathrm{L}$ of buffer NT1. After an incubation step at $95^{\circ} \mathrm{C}$ for $10 \mathrm{~min}$, the samples were centrifuged at $11000 \times g$ for $1 \mathrm{~min}$. Then, $25 \mu \mathrm{L}$ of proteinase $\mathrm{K}$ was added to $200 \mu \mathrm{L}$ of the supernatant for incubation at $70{ }^{\circ} \mathrm{C}$ for $10 \mathrm{~min}$. The remaining steps followed the manufacturer's instructions. DNA purity and quantification were assessed with a NanoDrop spectrophotometer (Thermo Fisher Scientific, Wilmington, DE, USA).

\subsubsection{Real-Time PCR for Microbial Analysis of Stool}

Real-time PCR was performed in sealed 96-well microplates using a LightCycler FastStart DNA Master SYBR Green kit and a LightCycler instrument (Hoffman-La Roche Ltd., Basel, Switzerland) as previously described [59]. The assay was performed in a $50 \mu \mathrm{L}$ sample containing a reaction mixture of $20 \mathrm{ng}$ of DNA, with $25 \mu \mathrm{L}$ of SsoAdvanced Universal SYBR Green (Bio-Rad, Hercules, CA, USA), $5 \mu \mathrm{L}$ of each primer, and $10 \mu \mathrm{L}$ of water. Primer sequences (Sigma-Aldrich, St. Louis, MO, USA) used to target the 16S rRNA gene of the bacteria and the conditions for PCR amplification reactions are listed in Table 1 . To verify the specificity of the amplicon, a melting curve analysis was performed via monitoring SYBR Green fluorescence in the temperature ramp from $60{ }^{\circ} \mathrm{C}$ to $97^{\circ} \mathrm{C}$. Data were processed and analyzed using the LightCycler software (Hoffman-La Roche Ltd., Basel, Switzerland). Standard curves were constructed using serial tenfold dilutions of bacterial genomic DNA, according to the data provided on the following webpage (http://cels.uri.edu/gsc/cndna.html). Bacterial genomic DNA (DSMZ, Braunschweig, Germany) was used as a standard. Genome size and the copy number of the 16S rRNA gene for each bacterial strain used as a standard were obtained from the NCBI Genome database (www.ncbi.nlm.nih.gov). Data are presented as the mean values of duplicate PCR analysis. 
Table 1. Primer sequences and real-time PCR conditions used for gut microbiota analysis.

\begin{tabular}{|c|c|c|c|}
\hline Bacterial Group & Primer Sequence $\left(5^{\prime}-3^{\prime}\right)$ & PCR Product Size (bp) & $\mathrm{AT}\left({ }^{\circ} \mathrm{C}\right)$ \\
\hline Firmicutes & $\begin{array}{l}\text { ATG TGG TTT AAT TCG AAG CA } \\
\text { AGC TGA CGA CAA CCA TGC AC }\end{array}$ & 126 & 45 \\
\hline Bacteroidetes & $\begin{array}{l}\text { CAT GTG GTT TAA TTC GAT GAT } \\
\text { AGC TGA CGA CAA CCA TGC AG }\end{array}$ & 126 & 45 \\
\hline Clostridium & $\begin{array}{l}\text { GCA CAA GCA GTG GAG T } \\
\text { CTT CCT CCG TTT TGT CAA }\end{array}$ & 239 & 45 \\
\hline Bacteroides & $\begin{array}{l}\text { ATA GCC TTT CGA AAG RAA GAT } \\
\text { CCA GTA TCA ACT GCA ATT TTA }\end{array}$ & 495 & 45 \\
\hline Universal & $\begin{array}{l}\text { AAA CTC AAA KGA ATT GAC GG } \\
\text { CTC ACR RCA CGA GCT GAC }\end{array}$ & 180 & 45 \\
\hline Enterococcus & $\begin{array}{c}\text { CCC TTA TTG TTA GTT GCC GCC ATC ATT } \\
\text { ACTCGT TGT ACT TCC CT TGT }\end{array}$ & 144 & 50 \\
\hline Prevotella & $\begin{array}{l}\text { CAC RGT AAA CGA TGG ATG CC } \\
\text { GGT CGG GTT GCA GAC C }\end{array}$ & 513 & 50 \\
\hline Bifidobacterium & $\begin{array}{l}\text { CGC GTC YGG TGT GAA AG } \\
\text { CCC CAC ATC CAG CAT CCA }\end{array}$ & 244 & 50 \\
\hline Roseburia & $\begin{array}{l}\text { TAC TGC ATT GGA AAC TGT CG } \\
\text { CGG CAC CGA AGA GCA AT }\end{array}$ & 230 & 50 \\
\hline Lactobacillus & $\begin{array}{l}\text { GAG GCA GCA GTA GGG AAT CTT C } \\
\text { GGC CAG TTA CTA CCT CTA TCC TTC TTC }\end{array}$ & 126 & 55 \\
\hline Akkermansia & $\begin{array}{l}\text { CAG CAC GTG AAG GTG GGG AC } \\
\text { CCT TGC GGT TGG CTT CAG AT }\end{array}$ & 327 & 55 \\
\hline
\end{tabular}

Abbreviations: AT, annealing temperature; bp, base pairs; $\mathrm{PCR}$, polymerase chain reaction.

\subsection{Fecal SCFAs and Organic Acids Determination}

Short-chain fatty acids (SCFAs) and organic acids (lactic and succinic acid) were measured using an Agilent 1200 series HPLC system with a refractive index-RI detector and with a UV detector. Approximately $200 \mathrm{mg}$ of feces were dissolved in $1 \mathrm{~mL}$ of ultrapure water, homogenized in a "mixer" for $15 \mathrm{~min}$, and centrifuged at $10,000 \times g$ for $10 \mathrm{~min}$; the supernatants were collected and stored at $-20^{\circ} \mathrm{C}$ until analysis. Briefly, fecal samples were filtered through a $0.22 \mu \mathrm{m}$ membrane filter (Orange Scientific, Braine-1'Alleud, Belgium) and injected $(40 \mu \mathrm{L})$ directly into an HPLC System consisting of a LaChrom L-7100 pump (Merck-Hitachi, Darmstadt, Germany) and an ion exchange Aminex HPX-87H column $(300 \times 7.8 \mathrm{~mm}$, BioRad Laboratories, Inc., Hercules, CA, USA $)$, operated at $65^{\circ} \mathrm{C}$. The mobile phase used was $0.003 \mathrm{M}$ solution of sulfuric acid at a flow rate of $0.6 \mathrm{~mL} / \mathrm{min}$. Data were collected and analyzed with a D7000 Interface (LaChrom, Merck-Hitachi, Fullerton, CA, USA) and using HPLC System Manager ${ }^{\circledR}$ Software 3.1.1 (MerckHitachi, Fullerton, CA, USA). Peak identification was based on the relative retention times determined by injection of standard solutions. Quantification was performed using calibration curves. Fecal SCFAs concentrations were expressed as mean micromoles per gram wet weight.

\subsection{Colon and Duodenum Analysis by Transmission Electron Microscopy (TEM)}

Duodenum and colon samples were immediately sectioned in small fragments of approximately $1 \mathrm{~mm}^{3}$ and fixed in $2.5 \%$ glutaraldehyde solution in $0.1 \mathrm{M}$ phosphate buffer $(\mathrm{pH}=7.2)$ for $2 \mathrm{~h}$. Sequential post-fixation was performed in $1 \%$ osmium tetroxide, for $1.5 \mathrm{~h}$, and $1 \%$ aqueous uranyl acetate, for $1 \mathrm{~h}$ in the dark. After rinsing with distilled water, samples were dehydrated in a graded acetone series (30-100\%) and embedded in an Epoxy resine (Fluka Analytical, Sigma-Aldrich, Darmstadt, Germany). Ultrathin sections obtained with a Leica EM UC6 (Leica Co, Vienna, Austria) ultramicrotome 
were mounted on copper grids and stained with lead citrate $0.2 \%$ for $10 \mathrm{~min}$. Observations were carried out on a TEM Tecnai G2 Spirit Bio Twin at 100 kV (FEI, Hillsboro, OR, USA), and images were processed using AnalySIS 3.2.

\subsection{Immunohistochemical Staining}

Cross-sections (10 $\mu \mathrm{m}$ thickness) of rat colon were cut with a cryostat (Leica CM3050S, Nussloch, Germany). Colon cryosection were fixed with an acetone:methanol mixture $(1: 1)$ at $20{ }^{\circ} \mathrm{C}$ for $2 \mathrm{~min}$ and then rehydrated in phosphate-buffered saline (PBS) $(3 \times 5 \mathrm{~min})$. After washing, sections were permeabilized with $0.5 \%$ Triton X-100 in PBS for 15 min and blocked for 40 min with $4 \%$ nonfat milk in $20 \mathrm{mM}$ Tris, pH 7.2, and $150 \mathrm{mM} \mathrm{NaCl}$. The sections were incubated with primary antibodies: rabbit polyclonal anti-ZO-1 (ab96587, Abcam, Cambridge, MA, USA) and mouse monoclonal anti-occludin (OC-3F10, 33-1500, Life Tecnologies, Carlsbad, CA, USA) in PBS containing 1\% BSA overnight at $4{ }^{\circ} \mathrm{C}$. After rinsing with PBS $(3 \times 5 \mathrm{~min})$, the sections were incubated with the secondary fluorescent antibody Alexa Fluor 488-conjugated goat anti-rabbit IgG or Alexa Fluor 568-conjugated donkey anti-mouse IgG (1:200; Molecular Probes, Life Technologies, Paisley, UK) and 4',6-diamidino-2-phenylindole (DAPI, nuclei dye), for $1 \mathrm{~h}$ at room temperature. After incubation, the sections were washed with PBS $(3 \times 5 \mathrm{~min})$, and the slides were mounted using the Glycergel mouting medium (Dako, Carpinteria, CA, USA). Anti-ZO-1 and anti-occludin immunostaining samples were imaged using a confocal fluorescence microscope (LSM 710, Carl Zeiss, Gottingen, Germany).

\subsection{Hepatic Histological Analysis}

Hepatic tissue samples were fixed directly in $10 \%$ neutral buffered formalin solution and embedded in paraffin wax. Paraffin blocks were cut to sections of $5 \mu \mathrm{m}$ using a microtome (HM325, Thermo Fisher Scientific, Waltham, MA, USA). Hematoxylin-eosin (H\&E) staining was performed according to the manufacturer's guidelines (Merck Millipore, Darmstadt, Germany). Digital images of tissue slices were captured using a Zeiss microscope Mod. Axioplan 2 (Zeiss, Jena, Germany).

Oil Red O staining was performed on frozen liver sections $(5 \mu \mathrm{m})$ previously fixed in $10 \%$ formalin for $5 \mathrm{~min}$ as previously described [60]. Briefly, slides were rinsed three times with absolute propylene glycol and then placed in $0.5 \%$ Oil Red O stain solution in propylene glycol for 30 min before being rinsed with $85 \%$ propylene glycol for $1 \mathrm{~min}$ and counterstained with hematoxylin. Thereafter, the slides were washed with distilled water and mounted with aqueous mounting medium (Sigma, St. Louis, MO, USA). Sections were observed with a Zeiss microscope Mod. Axioplan 2 (Zeiss, Jena, Germany).

\subsection{Quantification of Hepatic Triglycerides}

Hepatic triglycerides levels were measured using a Triglycerides Colorimetric Assay kit (1155010, Cromatest $^{\circledR}$, Linear Chemicals, Barcelona, Spain). Briefly, $50 \mathrm{mg}$ of frozen tissue were homogenized in $1 \mathrm{~mL}$ of isopropanol using a potter Elvehjem homogenizer (ThermoFisher, Waltham, MA, USA). The homogenate was sonicated and then centrifuged at $1000 \times g$ for $5 \mathrm{~min}$ at $4{ }^{\circ} \mathrm{C}$. Triglycerides were detected at $450 \mathrm{~nm}$ using an enzymatic-photometric analyzer (BIOTEK ${ }^{\circledR}$, Synergy HT, Winooski, VT, USA).

\subsection{Hepatic Mitochondria Bioenergetics}

Hepatic mitochondria were isolated in homogenization medium containing $250 \mathrm{mM}$ sucrose, $10 \mathrm{mM}$ HEPES (pH 7.4), $0.5 \mathrm{mM}$ EGTA, and 0.1\% fat-free bovine serum albumin (BSA) [61,62]. After homogenization of the minced blood-free hepatic tissue, the homogenate was centrifuged at $800 \times \mathrm{g}$ for $10 \mathrm{~min}$ at $4{ }^{\circ} \mathrm{C}$. The supernatant was spun at $10,000 \times \mathrm{g}$ for $10 \mathrm{~min}$ at $4{ }^{\circ} \mathrm{C}$ to pellet mitochondria, which were re-suspended in a final washing medium. EGTA and BSA were omitted from the final washing medium, adjusted at $\mathrm{pH}$ 7.4. Mitochondrial integrity was evaluated by measuring citrate synthase activity (CS), in the presence and absence of detergent ( $93 \pm 2.5 \%$ of intact mitochondria after isolation). CS serves as a measure for membrane integrity since citrate synthase is located in the 
inner mitochondrial membrane, and thus should not be present in suspensions of mitochondria with intact membranes. Protein content was determined by the biuret method calibrated with BSA [63].

\subsubsection{Mitochondrial Permeability Transition (MPT)}

Mitochondrial swelling was estimated by changes in light scattering, as monitored spectrophotometrically at $540 \mathrm{~nm}$, as previously described [64]. Reactions were carried out at $25{ }^{\circ} \mathrm{C}$ and $\mathrm{Ca}^{2+}(20 \mathrm{nmol})$ was added to the preparation after the start of the experiment. The assays were started by the addition of mitochondria $(1 \mathrm{mg})$ to $2 \mathrm{~mL}$ of swelling medium ( $200 \mathrm{mM}$ sucrose, $10 \mathrm{mM}$ Tris-MOPS, $1 \mathrm{mM} \mathrm{KH}{ }_{2} \mathrm{PO}_{4}$ and $10 \mu \mathrm{M}$ EGTA, pH 7.4) supplemented with $2 \mu \mathrm{M}$ rotenone and $5 \mathrm{mM}$ succinate. To confirm the relationship between membrane permeability transition (MPT) induction and mitochondrial swelling, cyclosporine A $(0.25 \mu \mathrm{M}$, a known MPT inhibitor) was added to the mitochondrial preparation before the addition of calcium. All the experiments were performed in triplicate.

\subsubsection{Mitochondrial Respiration (Oxygen Consumption)}

Oxygen consumption of isolated mitochondria was polarographically monitored with a Clark oxygen electrode (Oxygraph, Hansatech Instruments Ltd., Cambridge, UK) as previously described [61]. Mitochondria ( $1 \mathrm{mg}$ ) were suspended under constant magnetic stirring, at $25{ }^{\circ} \mathrm{C}$, in $1.4 \mathrm{~mL}$ of standard respiratory buffer containing $130 \mathrm{mM}$ sucrose, $50 \mathrm{mM} \mathrm{KCl}, 5 \mathrm{mM} \mathrm{MgCl}, 5 \mathrm{mM} \mathrm{KH}_{2} \mathrm{PO}_{4}$, $50 \mu \mathrm{M}$ EDTA, and $5 \mathrm{mM}$ HEPES ( $\mathrm{pH}$ 7.4) and $2 \mu \mathrm{M}$ rotenone. Mitochondria were energized with succinate $(5 \mathrm{mM})$ and state 3 respiration was induced by the addition of ADP $(200 \mathrm{nmol})$. After the phosphorylation of the ADP to ATP, respiratory rate became slower (state 4). The respiratory control ratio (RCR) was calculated by the ratio between the state 3 and the state 4 respirations and used as a parameter of mitochondrial integrity. The uncoupled respiration was also measured in the presence of carbonylcyanide-P-trifluoromethoxyphenylhydrazon (FCCP, $1 \mu \mathrm{M})$. FCCP is an ionophore that uncouples oxidative phosphorylation by inducing artificial proton permeability in the mitochondria, stimulating the maximum respiration rate. The $\mathrm{ADP} / \mathrm{O}$ ratio was calculated by the ratio between the amount of ADP added and the $\mathrm{O}_{2}$ consumed during the state 3 respiration.

\subsubsection{Mitochondrial Membrane Potential $(\Delta \Psi)$}

Mitochondrial membrane potential $(\Delta \psi)$ was estimated using an ion-selective electrode to measure the distribution of tetraphenylphosphonium $\left(\mathrm{TPP}^{+}\right)$as previously described $[62,64]$ using an $\mathrm{Ag} / \mathrm{AgCl}_{2}$ electrode as reference. The entrance of $\mathrm{TPP}^{+}$in mitochondria was determined by $\mathrm{TPP}^{+}$ concentration decreasing in the medium, measured by electrode potential. Briefly, mitochondria (1 mg) were suspended by gentle stirring in $1.4 \mathrm{~mL}$ of the standard respiratory buffer (as in mitochondrial respiration) supplemented with $3 \mu \mathrm{M} \mathrm{TPP}{ }^{+}$and energized by adding $5 \mathrm{mM}$ succinate. To avoid complex I contribution due to possible endogenous substrates contribution and to prevent retrograde electron flow from the ubiquinone pool back to complex I, $2 \mu \mathrm{M}$ of rotenone, a complex I inhibitor was added. After the steady-state distribution of TPP+ occurred, ADP $(200 \mathrm{nmol})$ was added to initiate the phosphorylative cycle. The electrode was calibrated with $\mathrm{TPP}^{+}$assuming Nernstian distribution of the ion across the synthetic membrane, and $\Delta \Psi$ is expressed in - $\mathrm{mV}$. A matrix volume of $1.1 \mu \mathrm{L} / \mathrm{mg}$ protein was assumed. The measured parameters were membrane potential (-mV), lag phase (seconds), and repolarization (-mV). Respiratory rates and $\Delta \Psi$ were simultaneously measured.

\subsection{Gene Expression by Quantitative Real-Time PCR Analysis}

Total RNA extraction from flash frozen liver was performed with PureLink RNA Mini Kit (12183018A, Ambion, Thermo Fisher Scientific, Carlsbad, CA, USA) according to the manufacturer's instructions. Total RNA extraction from colon tissue samples was performed using a Trizol protocol (93289, Sigma Aldrich; St. Louis, MO, USA), and stored overnight at $-80^{\circ} \mathrm{C}$. RNA concentration from liver was determined by Experion Automated Electrophoresis Station (Bio-Rad, Hercules, CA, USA). 
The concentration of total RNA from colon samples was measured by Nano Chip ${ }^{\circledR}$ kit in Agilent 2100 bioanalyzer (2100 expert software, Agilent Technologies, Walbronn, Germany). RNA integrity (RIN, RNAIntegrity Number) and purity (A260/A280) of all RNA samples were measured by Nano Chip ${ }^{\circledR}$ kit in Agilent 2100 Bioanalyzer (2100 expert software, Agilent Technologies, Walbronn, Germany) and ND-1000 ${ }^{\circledR}$ spectrophotometer (NanoDrop Tecnhologies, Wilmington, DE, USA), respectively.

In the hepatic samples, reverse transcription into cDNA was carried out by using the iScript Select cDNA Synthesis Kit (Bio-Rad, Hercules, CA, USA) following the manufacturer's instructions. The colonic cDNA was synthesized from RNA using a Xpert cDNA Synthesis Mastermix (GK81.0100, GRISP, Porto, Portugal) following the manufacturer's instructions. cDNA samples were then stored at $-20{ }^{\circ} \mathrm{C}$ until use.

To analyze genes of interest in colon tissue, gene expression quantification was performed as previously described [47]. Real-time PCR were conducted with a SYBR Green real-time PCR kit (Bio-Rad, Hercules, CA, USA), following the manufacturer's recommendations and gene specific-primers for ZO-1 (Tjp1, Unique Assay ID: qRnoCID0001801), occludin (ocln; Unique Assay ID: qRnoCID0005733, Bio-Rad, Hercules, CA, USA), and mucin-2 (muc2; Unique Assay ID: qRnoCID0003629 Bio-Rad), which were normalized with GeNorm algorithm, where gene stability was attained with glyceraldehyde 3-phosphate dehydrogenase (GAPDH) and hypoxanthine-guanine phosphoribosyltransferase (HPRT). The relative expression ratio of each of the target gene was computed on the basis of $\Delta \Delta \mathrm{Ct}$ $(2-\Delta \Delta \mathrm{Cp})$ values

In liver tissue, a predesigned 96-well Fatty Liver panel (SAB Target List, R96; 10046947, Bio-Rad, Hercules, CA, USA) for SYBR ${ }^{\circledR}$ Green detection (Bio-Rad, Hercules, CA, USA) were used following the manufacturer's instructions. This array includes genes for insulin signaling, adipokines, the inflammatory response, apoptosis, and carbohydrate and lipid metabolism in the liver. Gene expression was performed by SYBR-Green-based real time quantitative PCR using a StepOnePlus PCR system (Applied Biosystems, Foster City, CA, USA).

\subsection{Statistical Analysis}

Results are expressed as mean \pm standard error of the mean (SEM). Data was compared and analyzed using Student's unpaired $t$ test for normally distributed data or the Mann Whitney test for non-normally distributed data. One-way or two-way ANOVA followed by Bonferroni post hoc test was used as appropriate. Repeated measures ANOVA, followed by Bonferroni post-hoc test, was used to compare glucose levels throughout the GTT and ITT assays. Values of $p<0.05$ were considered statistically significant. GraphPad Prism for Windows (Version 6.0, GraphPad Software) was used for all statistical analysis.

\section{Results}

\subsection{Phenolic Composition of Blueberry Juice}

The phenolic composition of $\mathrm{BJ}$ was evaluated using the UV-vis spectra obtained on-line from a PDA detector, after chromatographic separation. The chromatographic profile obtained for the BJ is represented in Supplementary Materials, Figure S1. The main classes of phenolic compounds detected were hydroxycinnamic acids (peaks 1 to 3 ) and anthocyanins (peaks 4 to 11). Peaks 1 to 3 exhibited spectra profiles characteristic of caffeic or ferulic acid derivatives, with UV maxima near 250 and $324 \mathrm{~nm}$. The other chromatographic peaks (4 to 11) were identified as anthocyanins due to the presence of very characteristic spectra, with a peak between 240 and $280 \mathrm{~nm}$ (band II) and a strong visible peak between 450 and $560 \mathrm{~nm}$.

\section{2. $B W$ and Energy Intake}

BW remained unchanged following the sustained BJ consumption, despite the increased consumption of BJ (and consequent increase of carbohydrate load) that paralleled a higher urine output 
$(p<0.05)$. No statistical differences were recorded on solid food ingestion and total energy intake between groups (Table 2).

Table 2. BW variation and cumulative energy intake during the experimental protocol.

\begin{tabular}{cccc}
\hline & Parameters & CTRL & BJ \\
\hline \multirow{3}{*}{ Body weight } & Initial (g) & $461.00 \pm 14.00$ & $472.30 \pm 14.61$ \\
& Final (g) & $510.60 \pm 20.85$ & $532.40 \pm 24.42$ \\
& Delta (g) & $49.57 \pm 8.71$ & $60.13 \pm 10.80$ \\
\hline \multirow{4}{*}{ Intakes } & Food (g/rat/week) & $164.90 \pm 2.43$ & $162.50 \pm 2.62$ \\
& Drink (mL/rat/week) & $210.20 \pm 6.42$ & $323.40 \pm 11.20^{* * *}$ \\
& Total calories (Kcal/rat/week) & $519.30 \pm 7.65$ & $542.90 \pm 8.51$ \\
& Carbohydrates (Kcal/rat/week) & $352.70 \pm 5.89$ & $382.20 \pm 5.77^{* * *}$ \\
& Lipids (Kcal/rat/week) & $44.52 \pm 0.66$ & $43.16 \pm 0.67$ \\
& Proteins (Kcal/rat/week) & $122.00 \pm 1.80$ & $118.80 \pm 1.95$ \\
\hline Urine Output & Urine volume (mL/day) & $19.43 \pm 2.68$ & $42.25 \pm 6.41^{* *}$ \\
\hline
\end{tabular}

\subsection{Glycemic and Insulinemic Profiles}

After BB consumption, serum glucose and insulin levels were not significantly altered in both fasting and postprandial conditions (Table 3). In GTT assay, blood glucose levels were transiently higher in the BJ group soon after the intraperitoneal glucose challenge [at 15 and $30 \mathrm{~min}(p<0.01$ and $p<0.05$, respectively)] but quickly recovered in the following time-points, comparable to the control group. Accordingly, no statistical changes were found in AUC values of GTT $(p>0.05)$ nor in peripheral insulin sensitivity surrogates (ITT, kITT, HOMA-IR) (Table 3).

Table 3. Glycemic and insulinemic profiles.

\begin{tabular}{|c|c|c|}
\hline Parameter & CTRL & BJ \\
\hline Fasting glucose (mg/dL) & $101.30 \pm 2.29$ & $99.50 \pm 2.26$ \\
\hline Postprandial glucose (mg/dL) & $149.30 \pm 9.40$ & $159.00 \pm 11.15$ \\
\hline \multicolumn{3}{|l|}{ Glucose levels (mg/dL) during GTT } \\
\hline 0 min after glucose load & $100.9 \pm 1.53$ & $99.71 \pm 2.32$ \\
\hline 15 min after glucose load & $314.4 \pm 21.98$ & $412.10 \pm 14.19^{* *}$ \\
\hline 30 min after glucose load & $342.00 \pm 37.55$ & $428.40 \pm 6.121 *$ \\
\hline 60 min after glucose load & $248.10 \pm 30.30$ & $289.70 \pm 16.01$ \\
\hline 120 min after glucose load & $199.30 \pm 18.14$ & $185.60 \pm 7.81$ \\
\hline $\mathrm{AUC}_{\mathrm{GTT}}$ & $30,313.00 \pm 2887.00$ & $35,174.00 \pm 868.70$ \\
\hline Fasting insulin (mU/L) & $0.65 \pm 0.05$ & $0.61 \pm 0.11$ \\
\hline Postprandial insulin (mU/L) & $1.02 \pm 0.21$ & $1.24 \pm 0.15$ \\
\hline \multicolumn{3}{|l|}{ Glucose levels (mg/dL) during ITT } \\
\hline 0 min after insulin injection & $100.80 \pm 1.82$ & $99.50 \pm 2.79$ \\
\hline 15 min after insulin injection & $97.57 \pm 4.36$ & $103.10 \pm 4.58$ \\
\hline 30 min after insulin injection & $74.57 \pm 2.37$ & $80.25 \pm 4.97$ \\
\hline 45 min after insulin injection & $60.57 \pm 2.06$ & $67.38 \pm 3.91$ \\
\hline $60 \mathrm{~min}$ after insulin injection & $58.86 \pm 2.52$ & $63.25 \pm 2.58$ \\
\hline 120 min after insulin injection & $55.43 \pm 5.59$ & $64.50 \pm 5.26$ \\
\hline $\mathrm{AUC}_{\mathrm{ITT}}$ & $8120.00 \pm 291.70$ & $8815.00 \pm 317.20$ \\
\hline kITT (\% min) & $0.68 \pm 0.06$ & $0.52 \pm 0.06$ \\
\hline HOMA-IR & $3.26 \pm 0.60$ & $3.86 \pm 0.72$ \\
\hline
\end{tabular}

Data are presented as mean \pm SEM ( $n=6 / 8$ per group). AUC, area under curve; GTT, glucose tolerance test; HOMA-IR, homeostatic model assessment of insulin resistance; ITT, insulin tolerance test; kITT, glucose disappearance rate for ITT; ${ }^{*} p<0.05$ and ${ }^{* *} p<0.01$ vs. CTRL group. 


\subsection{Intestinal Microbiota and Gut Barrier Integrity}

To assess the impact of a sustained BB consumption on GM composition and function, we next analyzed microbiota and SCFAs/organic acids composition in feces along with colonic ultra-structural morphology, intestinal permeability, and systemic inflammation. While fecal microbiota composition remained unchanged between the two groups (Figure 1A), a significant increase in succinic acid $(p<0.05)$ was detected in the BJ-treated rats (Figure 1B). Moreover, TEM analysis did not reveal any alteration in colonic barrier ultra-organization, namely in the intercellular junctions (Figure 1C), which was further corroborated by the expression of ZO-1, occluding, and mucin-2 genes, the three key players involved in the maintenance of epithelial integrity (Figure 1D). Correspondingly, serum endotoxemia (LPS) and inflammation (hs-CRP) remained unchanged in both experimental groups (Figure 1E,F).

A)

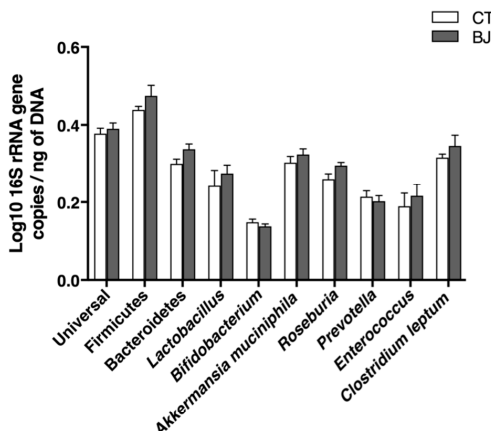

C)

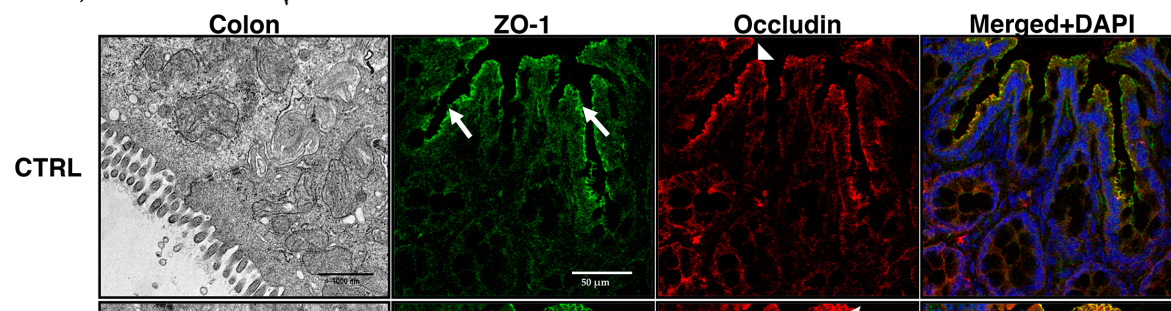

BJ

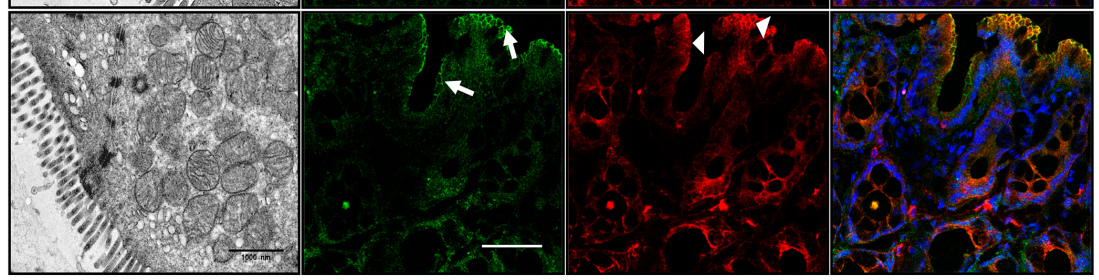

D)

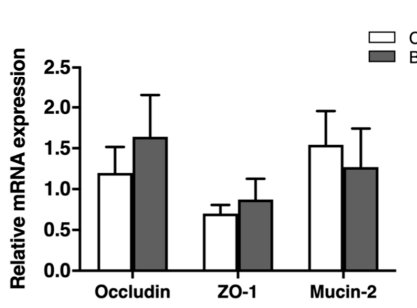

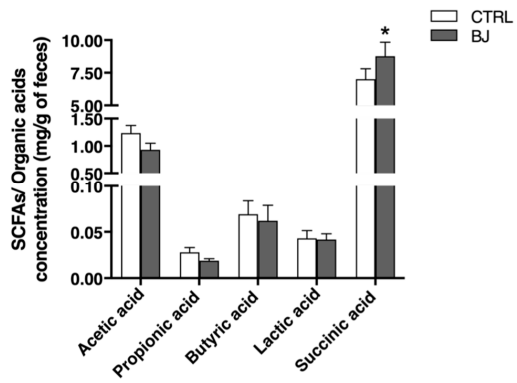

E)

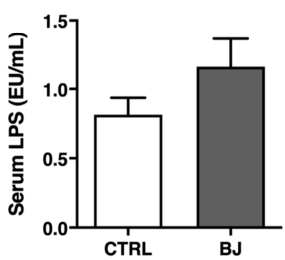

F)

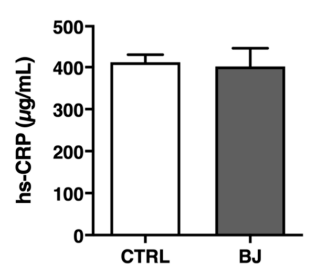

Figure 1. Gut microbiota composition (A), SCFAs, and organic acids (B) in feces; ultrastructural distribution of tight junctions and representative confocal images of colon section stained for ZO-1 (arrow) and occludin (arrowhead) (C) and mRNA expression (D) of key players of tight junctions; serum LPS (E) and hs-CRP (F) concentrations. Data are presented as mean $\pm \operatorname{SEM}(n=6-8 /$ group); * $p<0.05$ vs. CTRL group.

\subsection{Serum Antioxidant Status and Metabolomic Profile}

The serum antioxidant effect provided by this BJ consumption was evaluated by FRAP and ABTS ${ }^{\bullet+}$ assays. As foreseen, BJ-treated rats presented higher serum TAS ( $p<0.01$, Figure 2A), along with increased serum ABTS $^{\bullet+}$ inhibition percentage $(p<0.01$, Figure 2B). 
A)

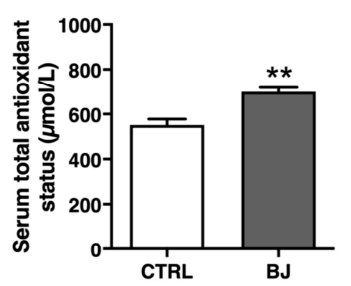

B)

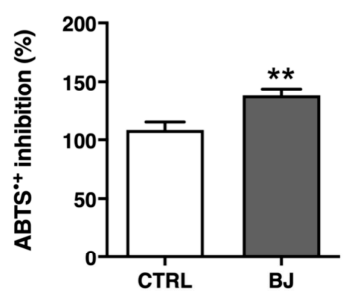

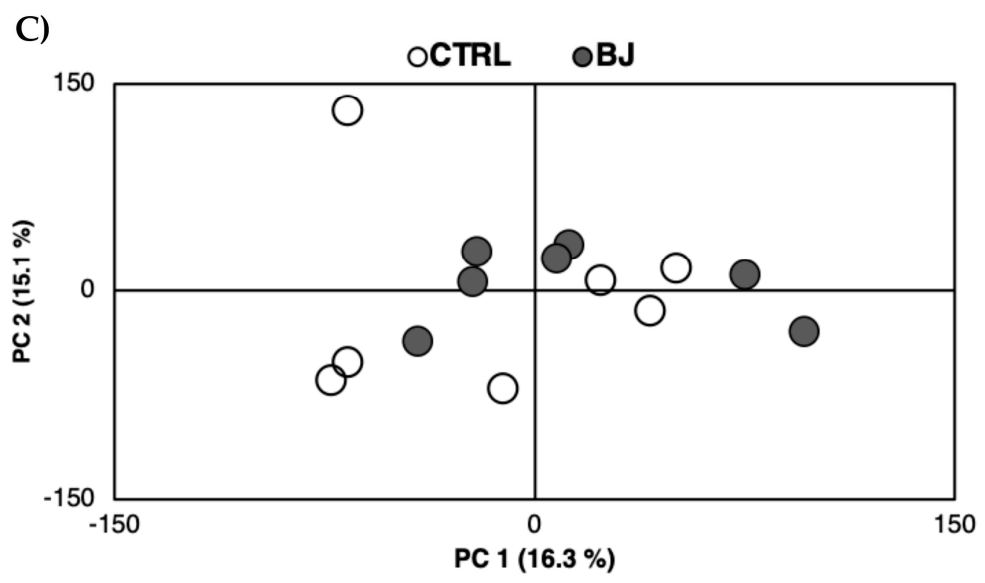

D)

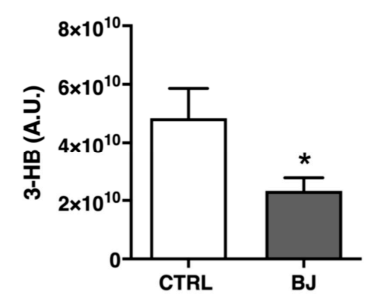

E)

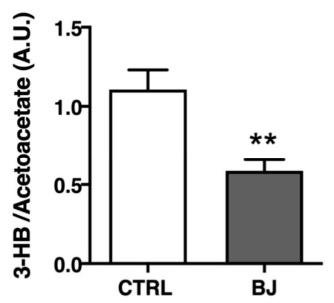

Figure 2. Serum antioxidant capacity evaluated by FRAP (A) and ABTS (B) assays; principal component analysis (PCA) scores plot obtained by multivariate analysis of ${ }^{1} \mathrm{H}$ NMR spectra of serum data (C); Serum levels of 3-hydroxybutyrate (3-HB) (D) and 3-HB/acetoacetate ratio (E). Data are presented as mean $\pm \operatorname{SEM}(n=6-8 /$ group $){ }^{*} p<0.05$ and ${ }^{* *} p<0.01$ vs. CTRL group.

To scrutinize the metabolomic profile between the control and BJ-supplemented animals, a nontargeted ${ }^{1} \mathrm{H}$ NMR-based metabolic analysis was further performed, allowing for the simultaneous assessment of an array of serum metabolites. The resulting spectral profile identified 22 metabolites (Supplementary Materials, Table S1) without any global metabolic discrimination between groups (Figure 2C), notwithstanding the significant reduction $(p<0.05)$ of 3-HB and 3-HB/acetoacetate ratio in serum of BJ-supplemented rats (Figure 2D,E).

\subsection{Serum and Hepatic Lipid Profile and Function}

As shown in Table 4, comparable values were obtained for both groups regarding serum/hepatic lipid profiles as well as absolute liver weights. These results were substantiated by the regular histologic appearance without signs of lipid deposition observed in hepatic H\&E and Oil-red-O stained sections, respectively (Figure 3). Likewise, similar serum GPT and GOT activities concurrently hint at a preserved liver function following BJ consumption (Table 4). 
Table 4. Serum lipid profile and hepatic parameters.

\begin{tabular}{ccc}
\hline Parameter & CTRL & BJ \\
\hline Serum lipid profile & & \\
\hline TGs $(\mathrm{mg} / \mathrm{dL})$ & $130.00 \pm 16.34$ & $153.10 \pm 16.09$ \\
\hline Total-C $(\mathrm{mg} / \mathrm{dL})$ & $71.25 \pm 3.37$ & $72.25 \pm 5.28$ \\
\hline LDL-C $(\mathrm{mg} / \mathrm{dL})$ & $20.75 \pm 1.51$ & $19.50 \pm 1.19$ \\
\hline HDL-C $(\mathrm{mg} / \mathrm{dL})$ & $44.75 \pm 1.99$ & $44.63 \pm 7.46$ \\
\hline TGs/HDL-C ratio & $3.04 \pm 0.37$ & $3.65 \pm 0.54$ \\
\hline Hepatic parameter & & \\
\hline Liver weight $(\mathrm{g})$ & $13.20 \pm 0.44$ & $14.28 \pm 0.69$ \\
\hline Liver weight/BW $(\mathrm{g} / \mathrm{kg})$ & $25.94 \pm 0.62$ & $26.85 \pm 0.55$ \\
\hline TGs $(\mathrm{mg} / \mathrm{g}$ tissues $)$ & $12.34 \pm 0.88$ & $12.04 \pm 0.49$ \\
\hline GPT $(\mathrm{U} / \mathrm{L})$ & $35.50 \pm 1.96$ & $36.29 \pm 2.39$ \\
\hline GOT $(\mathrm{U} / \mathrm{L})$ & $67.13 \pm 3.12$ & $68.29 \pm 6.30$ \\
\hline
\end{tabular}

Data are presented as mean \pm SEM ( $n=6 / 8$ per group). BW, body weight; GPT, glutamic-pyruvic transaminase; GOT, glutamic pyruvic transaminase; HDL-C, high-density lipoprotein cholesterol; LDL-C, low-density lipoprotein cholesterol; TGs, triglycerides; Total-C, Total-cholesterol.

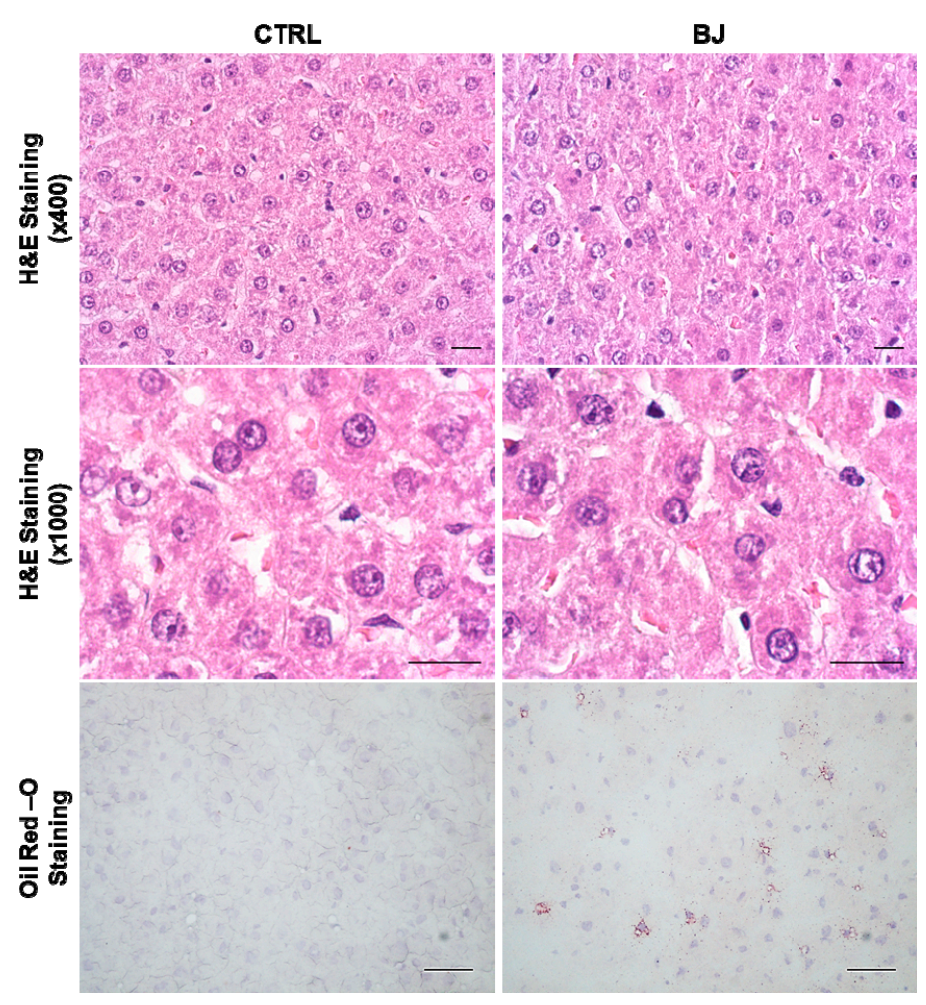

Figure 3. Representative images of hepatic structure and lipid accumulation evaluated by H\&E $(\times 400$ and $\times 1000$ magnification) and Oil-Red-O staining ( $\times 400$ magnification), respectively, in the CTRL and BJ-treated rats; scale bar $=20 \mu \mathrm{m}$.

\subsection{Hepatic Mitochondrial Bioenergetics}

In order to better understand the long-term effects of $\mathrm{BB}$ consumption on liver tissue, we assessed several parameters related with mitochondrial bioenergetics, an organelle with a crucial role in energy and metabolic regulation in the liver. Mitochondria have a limited capacity for accumulating calcium before undergoing the calcium-dependent mitochondria permeability transition (MPT), 
a phenomenon comprising the release of high molecular weight solutes from within the mitochondria, probably through the formation of a multi-channel pore. Mitochondrial swelling, an event that reveals mitochondrial permeability transition pore (mPTP) opening, was evaluated by presenting $20 \mathrm{nmol} \mathrm{Ca}^{2+}$ to mitochondrial preparations. In the presence of a relatively high $\mathrm{Ca}^{2+}$ dose, on pretreatment of hepatic mitochondria with cyclosporine A (MPT specific inhibitor), mitochondria retained aforesaid $\mathrm{Ca}^{2+}$ load and did not undergo $\mathrm{Ca}^{2+}$-dependent mitochondrial swelling, advocating isolated mitochondrial integrity (Figure 4A). Surprisingly, BJ induced a more pronounced decline in light scattering, indicating an increased susceptibility to undergo mitochondrial swelling, which will in turn reflect greater susceptibility to pore induction and mitochondrial uncoupling (Figure 4A).

A)

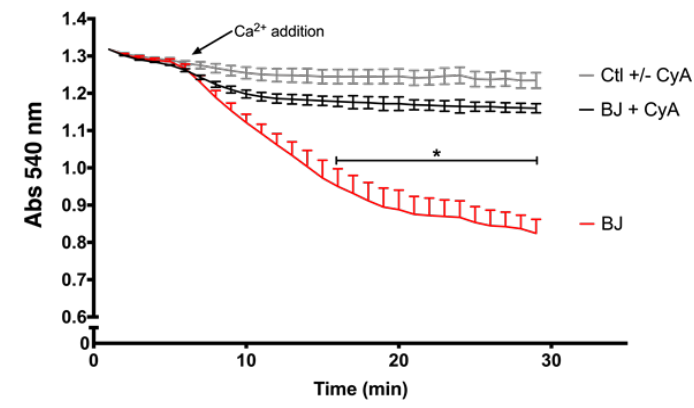

C)

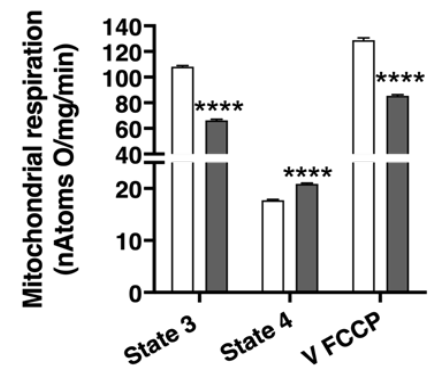

D)

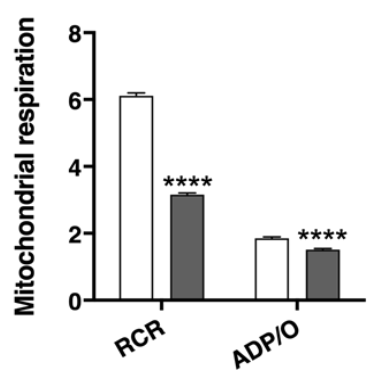

B)

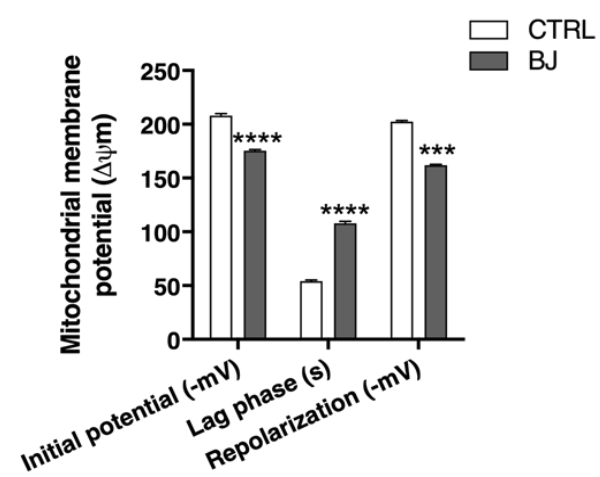

E)

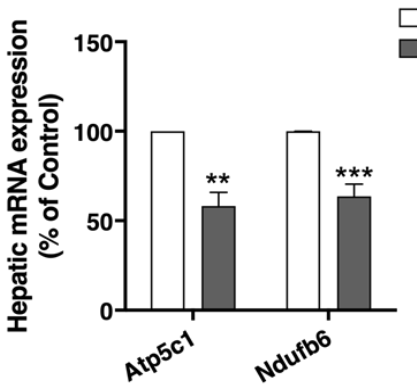

Figure 4. Hepatic mitochondrial function assessment: susceptibility to the induction of mitochondrial permeability transition (MPT) (A); mitochondrial membrane potentials and lag phase (B); parameters of mitochondrial respiration (C,D); hepatic mRNA expression of genes involved in mitochondrial respiratory chain $(\mathrm{E})$. Data are presented as mean $\pm \operatorname{SEM}(n=6-8 /$ group $){ }^{* *} p<0.01,{ }^{* * *} p<0.001$, **** $p<0.0001$ vs. CTRL group.

Membrane potential $(\Delta \psi)$ sustained by mitochondria is central for this organelle function and pinpoints its phosphorylative capacity. As seen in Figure 4B, BJ induced a significant reduction in initial $\Delta \psi$ (after substrate addition) and in repolarization $\Delta \psi$ (mitochondrial capacity to establish $\Delta \psi$ after ADP phosphorylation) ( $p<0.001)$. Moreover, the lag phase (time required for ADP phosphorylation), was significantly longer $(p<0.001)$ in hepatic mitochondria of BJ-supplemented animals. Mitochondrial respiration was further determined by evaluating oxygen consumption in energized mitochondria (succinate supply). BJ-isolated mitochondria showed a clear decline of respiratory capacity compared to the CTRL group. A decrease in mitochondrial state 3 (ADP-stimulated respiration) along with a significant increase in state 4 (resting state) respiration were observed $(p<0.001)$ in the mitochondria of BJ-treated rats (Figure 4C). Additionally, BJ supplementation also caused a significant decrease in uncoupled respiratory rate (V FCCP, a maximal respiratory activity stimulated by FCCP), suggesting that the phosphorylative system of hepatic mitochondria is impaired following a long-term BJ supplementation. Consistently, respiratory control ratio (RCR) was significantly decreased $(p<0.001)$ in hepatic mitochondria of BJ-treated animals. This functional parameter was determined by the ratio 
between state 3 and state 4 respiration and reflects the mitochondrial coupling between respiration and phosphorylation and efficiency. Moreover, the ADP/O ratio (which represents the number of ADP molecules that can be phosphorylated by one atom of oxygen consumed), a surrogate marker of mitochondrial oxidative phosphorylation efficiency, was also significantly decreased in BJ-treated rats (Figure 4D).

The expression of key genes encoding mitochondrial respiratory chain complexes was evaluated by RT-PCR. Interestingly, as shown in Figure 4E, both Atp5c1 and Ndufb6 were downregulated $(p<0.01)$ in animals supplemented with BJ when compared to the untreated CTRL animals. These two genes (Ndufb6 and Atp5c1) encode proteins of complex I (subunit NADH:ubiquinone oxidoreductase) and complex V (mitochondrial ATP synthase), respectively.

\subsection{Hepatic RNA Transcripts Encoding Functionally Diverse Cellular Targets}

A broad analysis of hepatic mRNA expression of BB phytochemical's conceivable cellular targets, from chief-metabolic players to inflammatory components, was performed in both experimental groups.

The hepatic mRNA expression of genes involved in fatty acid uptake and transport, fatty acids oxidation, lipolysis, and synthesis (lipogenesis) were analyzed by qRT-PCR. BB consumption significantly decreased the hepatic mRNA expression of genes related with fatty acid transport (Fabp1 and Slc27a5), fatty acid oxidation (Ppar- $\alpha$, Acadl, Acox1, Cpt1a, and Cpt2), and lipid synthesis (Dgat-2) (Figure 5). In opposition, an enhanced expression of mRNA levels of Scd1 (also lipogenic enzyme) $(p<0.005)$ was found in hepatic tissues. Yet, mRNA expression of some genes encoding lipogenic enzymes (Fasn and $L p l$ ) did not show any significant alteration. Regarding cholesterol metabolism, a significantly increased mRNA expression of Apoa1 (the major component of HDL) was found in the BJ group compared with the CTRL one (Figure 5). In addition, BJ supplementation significantly decreased mRNA expression of ApoC3, which encodes a small protein on the surface of VLDL and LDL. Hepatic alipoprotein (Apo) B and Apo E, Hmgcr and Ldlr mRNA expression were unchanged between experimental groups. In addition, the impact of BJ on cytochrome P450 2e1 (Cyp2e1) was also explored on the basis of its well-known influence in gluconeogenesis as well as in xenobiotic metabolism. Notably, Cyp2e1 mRNA expression was significantly decreased in animals supplemented with BJ (Figure 5). The expression levels of genes involved in glucose metabolism were also assessed. Gck, Pdk4, and Ptpn1 mRNA expression were downregulated in livers of BJ-treated rats despite normal G6pd mRNA expression (Figure 5). In addition, BJ treatment enhanced the Slc2a1 mRNA level (corresponding to the gene encoding glucose transporter, GLUT1), while mRNA expression of Slc2a2 and Slc2a4 genes (encoding GLUT2 and GLUT4, respectively) were unchanged (Figure 5).

Due to the anti-inflammatory properties described for BB in several pathological conditions $[65,66]$, we further underscored the expression of distinct inflammatory parameters. The mRNA expression of adiponectin receptors (Adipor1 and Adipor2), tumor necrosis factor receptor superfamily member

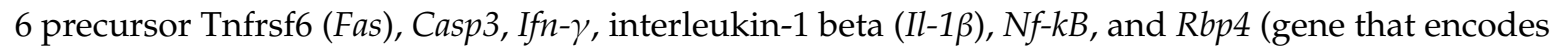
a recently identified adipokine: retinol binding protein 4) were significantly lower in animals supplemented with BJ when compared to the CTRL group (Figure 6). Moreover, the hepatic expression of the heat shock protein (Hsp90ab1) was remarkably decreased in animals treated with BJ (Figure 6). No significant changes were found in the expression of the Stat3 gene, a transcription factor involved in the downstream signaling of several cytokines and growth factors, as well as in the hepatic mRNA expression of tumor necrosis factor- $\alpha(\operatorname{Tnf}-\alpha)$ (Figure 6). 


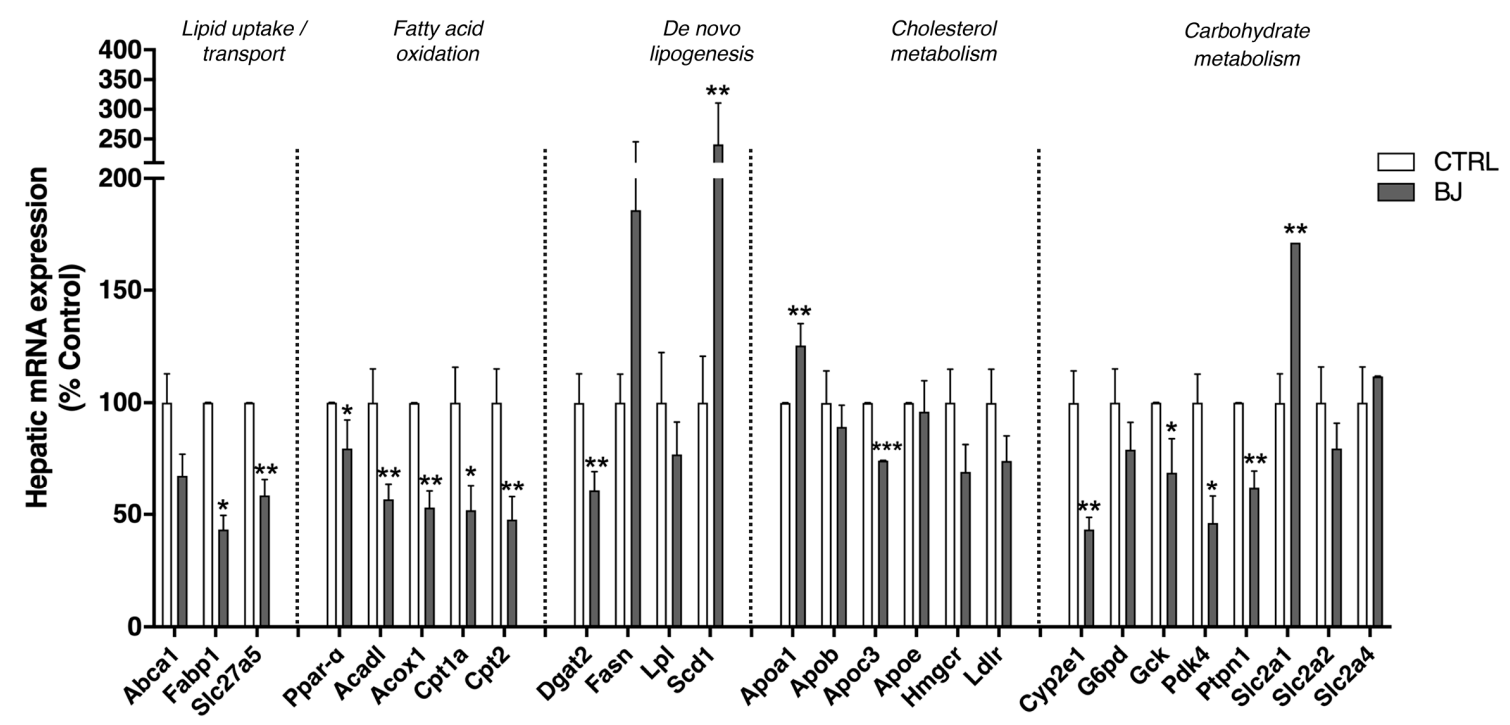

Figure 5. Hepatic mRNA expression of genes involved in fatty acid uptake/transport, fatty acid oxidation, and lipogenesis as well as cholesterol and carbohydrate metabolism. Data are presented as mean \pm SEM ( $n=5-6 /$ group); ${ }^{*} p<0.05,{ }^{* *} p<0.01,{ }^{* * *} p<0.001$ vs. CTRL group.

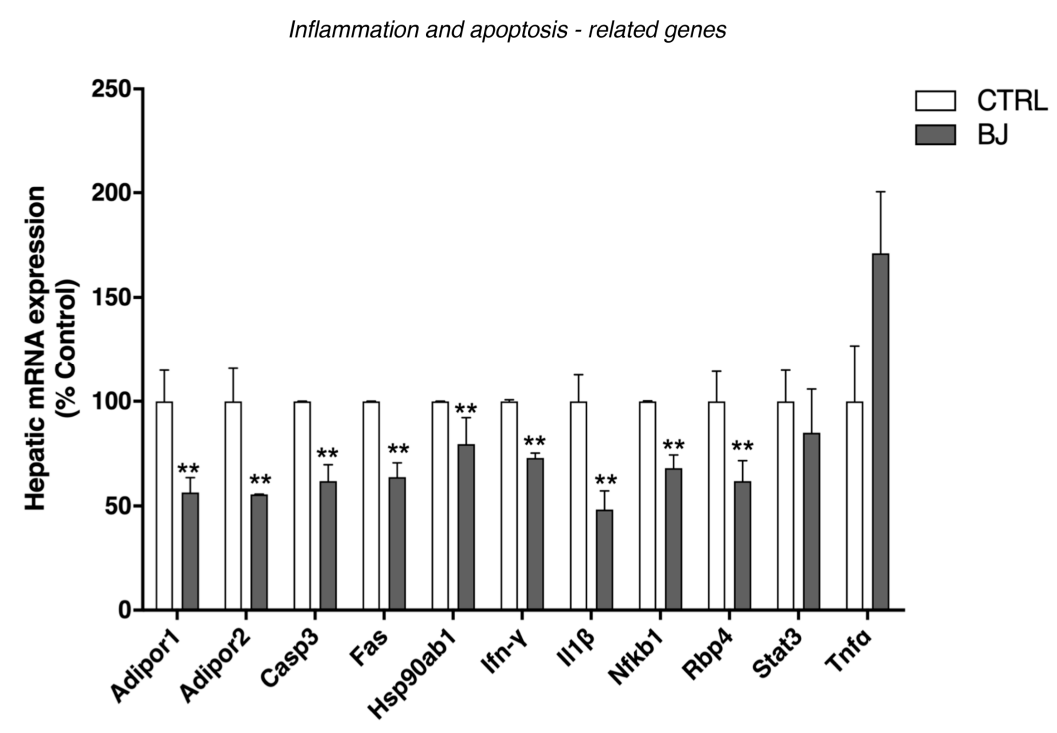

Figure 6. Hepatic mRNA expression of genes involved in inflammatory, stress response, and apoptotic processes. Data are presented as mean $\pm \operatorname{SEM}(n=5-6 /$ group $) ;{ }^{* *} p<0.01$ vs. CTRL group.

\section{Discussion}

Society globalization, time pressure, and the general concern surrounding a healthier lifestyle are major drivers to the rise of consumers' demand for "superfoods" aimed to reinforce overall health status. Blueberries are classically tagged as "superfruits" on the basis of their richness in a panoply of bioactive phytochemicals throughout their outer and inner layers [6]. An emergent trend of BB "prophylactic" consumption is presently widely scaled-up, not only as a food source but also as commercially available formulations of BB-derived functional foods and supplements whose regulatory oversight varies from country-to-country. In this context, uncertainties regarding their "real-life" efficacy and possible adverse effects subsist [67-69]. Accordingly, reliable and reproducible information from preclinical and human trials is still incongruent and requires a more in-depth elucidation to guide a healthier and safer consumption $[29,30,34,36,37]$. Herein, we designed an experimental study in healthy Wistar rats that were exposed to a BB supplementation regimen (BB whole-fruit). Particular attention was given to the dose employed and treatment duration mirroring a long-term human consumption scenario, 
and gut- and liver-related metabolic parameters were assessed on the basis of BB-health benefit claims within obesity-related metabolic diseases.

We observed a moderate increase in fluid and carbohydrates consumption in BB-supplemented rats, most likely due to the pleasant organoleptic properties of BB fruits. Regardless of the fact that BJ may represent an extra source of carbohydrates, overall BB low caloric content along with the increased urine output observed in BB-supplemented rats favored a final isocaloric intake between groups and the maintenance of comparable BW growth curves. In fact, the lack of BW changes is in line with previous preclinical studies on healthy Sprague-Dawley and Lister hooded rats supplemented with freeze-dried whole BB for short- and long-term periods ( 3 and 7 weeks), respectively [70,71].

BB fruits are well-documented in regards to their glucose-lowering and insulin-sensitizing effects in several in vitro studies and in diabetic animal models [72-77]. In our study, BB-supplemented rats efficiently managed the higher carbohydrates load arising from BB consumption, without significant interference in global glycemic and insulinemic profiles, which is also in concordance with previous studies in healthy conditions [78-80].

Once orally consumed, BB phytochemicals are largely metabolized by resident gut microflora whose individual fingerprints distinctively shape bioactive compounds bioavailability [81]. Besides this chief role on BB phytochemicals kinetics, GM is also modulated by BB prebiotic molecules (e.g., dietary fibers and unabsorbed polyphenols) with recognized benefits in distinct metabolic diseased conditions [21,81-83]. Collectively, these reasons prompted us to characterize GM composition, SCFA-derived metabolites, and overall intestinal integrity once BB supplementation is orally provided. Our results do not depict any significant changes in microbiota composition, despite a significant increase in fecal succinic acid, an organic acid produced by bacterial fermentation of carbohydrates for which important roles on intestinal and hepatic gluconeogenesis as well as lipid metabolism are currently underlined [84-86]. Moreover, these observations are in line with studies of Haraguchi and colleagues, who reported enhanced cecal succinate levels upon consumption of some dietary polyphenols without major changes in propionate levels and succinate-producing gut bacteria (e.g., Bacteroidetes phylum) [87]. Albeit we acknowledge that modern analytical approaches available for microbiome assessment (e.g., 16S rRNA gene sequencing) could better discriminate subtle changes in GM upon BB supplementation [88], the increment in fecal succinic acid levels reported herein hints at a metabolic adaptative response of resident gut bacteria community towards enhanced fermentation of dietary fibers and intrinsic gut health-promoting effects [89-91]. The physiological levels of epithelial integrity modulators (e.g., occludin, ZO-1, mucin) along with a regular colonic ultrastructural morphology and the absence of systemic endotoxemia and inflammation further corroborates this assumption.

Blueberry's health benefits are closely related with antioxidant activity $[13,92,93]$ mainly due to their high content in phenolic compounds (e.g., hydroxycinnamic acids, caffeic or ferulic acid derivatives, anthocyanins), which we have verified in our BJ samples, analogous to what has been previously reported [94]. FRAP and $\mathrm{ABTS}^{\bullet+}$ assays denoted a higher antioxidant capacity in serum samples of BB-supplemented rats, which is consistent with currently available preclinical and human data [95-97]. To decipher whether a long-term intake of $\mathrm{BB}$ could induce systemic metabolic effects, we conducted a non-targeted ${ }^{1} \mathrm{H}$ NMR-based metabolomic approach. The resultant principal component analysis (PCA) did not discriminate any segregation between two experimental groups. Yet, an unexpected and marked decrease in serum 3-HB ketone bodies and 3-HB/acetoacetate ratio was observed in BB-supplemented rats. Circulating ketone body levels are main surrogates of energy metabolism and have been traditionally looked upon as an evolutionary ancient fasting energy vector from liver to peripheral tissues (e.g., brain, skeletal muscle, heart) [98]. Nevertheless, their importance as vital metabolic and signaling mediators has been recently underscored, even under regular glucose supply conditions [99].

Bearing in mind that (i) ketogenesis is primarily carried out in the hepatic mitochondria [100] and (ii) BB-derived phytochemicals (e.g., antioxidant polyphenols) are able to regulate mitochondrial metabolism/biogenesis and are tagged as mitochondria-protecting agents [101-103], we next attempted 
to dissect the impact of this BB consumption in hepatic tissue, with a major focus on mitochondrial function. Livers displayed a similar macroscopic appearance, regular histomorphology, and lipid deposition, which is aligned with the normal serum lipid profile observed between experimental groups. Moreover, the comparable serum GPT and GOT aminotransferases activities classically score for hepatic function preservation in a clinical perspective [104,105]. However, at a subcellular level, long-term BB intake clearly triggered a mitochondrial-adaptative setting, featured by an accentuated bioenergetic remodeling in isolated hepatic mitochondria. Mitochondrial respiration supports an electric potential (measured with the $\mathrm{TPP}^{+}$electrode) and the decrease in this potential may result from an inhibitory effect at the level of the respiratory chain or due to an uncoupling effect (non-specific permeabilization of the membrane at the level of the internal membrane, or eventually the BJ has some ionophoretic property). These two effects can be simultaneous, and this is very likely, since respiratory state 4 rises significantly and V FCCP respiration is significantly inhibited. These two effects are reflected in an increase in the lag phase (the mitochondria take longer to phosphorylate the added ADP and do not phosphorylate it completely since the ADP/O lowers). Mitochondria are also important intracellular storage sites of the secondary messenger $\mathrm{Ca}^{2+}$, which accumulates in a direct relation with membrane potential. High concentrations of $\mathrm{Ca}^{2+}$ added to mitochondria in the presence of Pi promote the assemblage of a pore (permeability transition pore) that leads to loss of functional integrity of mitochondria (e.g., uncoupling) that cannot efficiently produce ATP.

In sum, the (i) mitochondrial swelling, a surrogate parameter of calcium-induced mPTP opening [106]; (ii) dissipation of the transmembrane electric potential $(\Delta \Psi)$, probably reflecting proton leakage or inhibitory effects at the respiratory chain, or both $[107,108]$; (iii) overall impaired phosphorylative system, stemmed from the increased lag phase time (reflecting more time spent for ADP phosphorylation), decreased uncoupled respiration (V FCCP), lower RCR (implying an inefficient capacity for substrate oxidation and ATP turnover) and decreased ADP/O flux ratio [mol of ATP synthesized per mol of $\mathrm{O}\left(1 / 2 \mathrm{O}_{2}\right)$ ] [109], collectively emphasize BB-derived phytochemicals ability to strongly impact mitochondrial respiratory control, in line with several reports focused on polyphenolic phytochemicals [110-112]. Moreover, a concomitant downregulation of mitochondrial respiratory complex I (Ndufb6) and complex V (Atp5c1) encoding genes further corroborates, at a molecular level, the mitochondrial functional data and is closely aligned with the dose-dependent decrease of ECT activity and oxidative phosphorylation observed in vitro when rat heart mitochondria were exposed to bilberry fruit anthocyanin-rich extracts [113].

To further underscore the first insights of BB-derived hepatic remodeling at a molecular level, we broadened our study through a transcriptomic analysis of functionally diverse cellular targets of BB phytochemicals encompassing energy-derived metabolic pathways, transcription factors, and inflammatory mediators. From the lipidic perspective, BB oral consumption triggered a pair-decreased mRNA transcripts of fatty acid transporter 5 (FATP5/Slc27a5) and fatty-acid binding protein-1 (FABP1), impaired hepatocyte fatty acid uptake, along with a collective transcriptional repression of Acadl, Acox-1, Cpt1a and Cpt2a encoding-genes, suggesting mitochondrial acyl-CoA uptake decline and successive fatty acid $\beta$-oxidation deceleration, which is in accordance with previously published data [114]. Interestingly, a concerted downregulation of PPAR- $\alpha$ gene, a transcription factor responsible for the induction of fatty acid transport/oxidation along with ketone biosynthesis and import, was also recorded. Taking into consideration that hepatic ketogenesis is a proxy of total hepatic fat oxidation $[115,116]$, future work will be critical to better understand the possible correlation between the transcriptomic fatty acid $\beta$-oxidation repression and the decreased circulating 3-HB contents detected in BB-treated rats. Ensuing inhibition of the expression of the lipogenic enzyme DGAT-2 may also be postulated as a downstream event of PPAR- $\alpha$ transcription factor repression [117]. In opposition, the SCD-1 gene, which encodes an enzyme that catalyzes the conversion of saturated into monounsaturated fatty acids, was found up-regulated in orally supplemented BB rats. Furthermore, a simultaneous up- and downregulation of ApoA1 and ApoC3 gene transcription, two major structural components of HDL and VLDL lipoproteins, respectively, were detected in 
the livers of $\mathrm{BB}$ experimental group without a significant translation in serum/liver lipid profile. Within the carbohydrate context, BB-induced transcriptomic remodeling also followed similar traits. Glucokinase (GCK), the principal hexokinase acting as the gatekeeper for hepatic glycolysis, was found downregulated upon BB-supplementation $[118,119]$. A similar fall in Pdk4 gene transcription (probably due to PPAR- $\alpha$ downregulation) was also observed and may correlate with decreased pyruvate availability for gluconeogenic processes [118-120]. This assumption is further corroborated by CYP2E1 gene repression for which an important role in the oxidative metabolism of gluconeogenic substrates is well-known [121,122]. Moreover, Ptpn1 gene downregulation is compatible with insulin signaling improvement and is aligned with previous reports denoting the ability of polyphenol anthocyanins to exert their insulin-sensitizing properties [94,123]. Collectively, BB-induced hepatic transcriptomic metabolic reprogramming observed herein hints at a repression of chief fuel sources and cellular energetic pathways (e.g., fatty acid $\beta$-oxidation, glycolysis, gluconeogenesis).

Finally, and on the basis of the anti-inflammatory potential of BB phytochemicals [124,125], we also assessed the transcriptomic profile of a panoply of inflammatory-related genes. A combined gene repression of NFkb1, cytokines (e.g., IFN-g, IL-1ß), adipokines (e.g., Adipor1 and Adipor2), and stress-element responses (e.g., Hsp90ab1) were unequivocally triggered by the BB supplementation. Besides their well-known antioxidant properties, BB phytochemicals also display the ability to modulate cellular pathways through epigenetic mechanisms encompassing DNA methylation, histone modifications, and posttranscriptional gene regulation of noncoding RNAs, constituting a link between external environmental cues and gene expression $[4,126]$. In this regard, we cannot overlook the probable "noncanonical" signaling rearrangement arising from BB phytochemicals-altered ketone bodies homeostasis. In fact, decreased 3-HB levels may also trigger chromatin remodeling through histone hypoacetylation and subsequent transcriptional repression $[115,116]$. Due to its reversibility, dietary-targeted epigenetics is an attractive approach for disease prevention and is often envisaged as a starting point of clinical intervention [127]. Taken together, and on the basis of the marked transcriptomic repression in metabolic, transcription factors, and inflammatory-related genes, future experimental studies are warranted to underscore the impact of long-term intake of BB on the epigenetic phenomena and their potential for disease prevention and/or intervention.

One emergent mechanism of action of dietary phytochemicals relies on their ability to act as hormetins, triggering adaptive cellular stress response pathways in both plants and humans [128]. Typically, the concept of hormesis has been adopted to describe the phenomenon where a given substance/condition is able to induce biologically opposite effects at different doses [129]. In other words, a hormetic response may occur when a mild stress (e.g., calorie restriction, exercise) activates intrinsic changes that enhance resistance to a more severe stress arising from higher doses of the same stressor or even from other less-specific stressors comprising oxidative, metabolic, and thermal stresses [130]. Altogether, the mitochondrial bioenergetic challenge and metabolic transcriptomic reprogramming presently disclosed portray a unified adaptive response to the nutritional challenge imposed by BB phytochemicals intake. Interestingly, mitohormesis is being widely disclosed in many model organisms and strongly implicated in metabolic health [131-134]. For instance, mitochondrial ECT modulation was found to reprogram energy metabolism towards cell survival and improved lifespan [135]. Remarkably, downregulation of ECT activity due to mitochondria-targeting xenobiotics in Caenorhabditis elegans resulted in cytoplasmic proteostasis restoration and suspected increased vitality later in life [136]. Moreover, mitochondrial bioenergetics remodeling may also encompass a central node in the fine-tuning of metabolic "switch" in fuel sources and catabolic/anabolic rates that optimize organism performance in varying nutrient states and physiological conditions [116,137]. Interestingly, the global repression of genes enclosing distinct metabolic pathways collectively hint for a "hibernated" energetic state upon BB supplementation. Conceivable altered ketogenesis, classically viewed as a spillover pathway from fat combustion, further reinforces a quiescent mitochondrial-related metabolomics. Supported by the notion that ketone body metabolism may be beneficial even in 
carbohydrate-laden states, the ketohormetic hypothesis has been recently postulated [116] and may actually intertwine with mitohormesis $[116,138]$ within this BB phytochemical challenge.

Since the hormetic response is a phenomenon where low doses of a stressor trigger opposite responses to high ones, the beneficial or toxic outcomes should be interpreted in the light of the non-linear biphasic hormetic dose-effect relationship [139]. Accordingly, the amounts of phytochemical cell stressors in fruits and vegetables consumed by humans in a regular diet are considered to fall within the low dose stimulatory range of concentrations; however, once they are consumed in the form of concentrated supplements, the doses may exceed the toxic threshold with potential adverse health consequences $[130,140]$. Remarkably, previous work also disclosed that hepatic tissue is able to hormetically cope with chemical stressors (ethanol) through a transcriptional adaptative response [141]. Considering that we only assessed a unique dose in a single-hit stress paradigm (BB consumption) along with the ambivalent redox nature of polyphenols [110], the beneficial or noxious consequences arising from this $\mathrm{BB}$ hepatic remodeling should be carefully interpreted. In a global perspective, no evident toxic effects were recorded. However, at a molecular level, BB intake may trigger distinct consequences. For instance, if the transcriptomics remodeling of some of the analyzed genes are effectively translated into the protein level, one can envisage both positive [anti-atherogenic properties (e.g., ApoA1 upregulation) and hepatic steatosis reversal (e.g., SCD-1 upregulation)] and negative [altered xenobiotic metabolism (e.g., acetaminophen, isoniazid, coumarin, ethanol), due to Cyp2E1 downregulation] outcomes [142-144]. Moreover, the mitochondrial "idle motion" observed herein may be beneficial at a basal condition and prelude optimal fitness but also be detrimental if not quickly reversed upon highly demanding operating challenges.

\section{Conclusions}

To the best of our knowledge, this is the first work providing molecular insights on the mitochondrial and metabolic effects of $\mathrm{BB}$ consumption in a healthy condition from a translational perspective. Collectively, the data presented herein hint at mitochondrial-related metabolic transcriptomic reprogramming, together with a concerted anti-inflammatory pre-conditioning. Future studies comprising prophylactic or interventional BB regimens in diseased conditions (two-hit experimental paradigms) and in both sexes will be of utmost importance to disclose tailored beneficial/toxic outcomes of this new dietary trend and guide evidence-based medicine.

Supplementary Materials: The following are available online at http://www.mdpi.com/1999-4923/12/11/1094/s1, Figure S1: Chromatographic profile of phenolic compounds in BJ, obtained with HPLC-PDA (320/530 nm), Table S1: Serum metabolites identified by $1 \mathrm{H}-\mathrm{NMR}$.

Author Contributions: Conceptualization, S.N., S.D.V., and F.R.; formal analysis, S.N.; investigation, S.N., S.D.V., I.P., A.A., R.F., J.S.T., A.F., L.S., S.S., and A.P.R.; resources, A.F., L.S., R.A.C., C.M.P., and M.M.P.; data curation, S.N., J.S.T., A.F., I.J., and A.P.R.; writing-original draft preparation, S.N. and S.D.V.; writing-review and editing, S.N., S.D.V., R.F., I.J., R.A.C., C.M.P., M.M.P., and F.R.; supervision, F.R., M.M.P., and C.C.; project administration, F.R.; funding acquisition, F.R. All authors have read and agreed to the published version of the manuscript.

Funding: This research was funded by the European Regional Development Fund (FEDER), through Programa Operacional Factores de Competitividade COMPETE2020 (CENTRO-01-0145-FEDER-000012-HealthyAging2020) and by National funds via Portuguese Science and Technology Foundation (FCT): Strategic Projects UID/NEU/04539/2013, UID/NEU/04539/2019, UIDB/04539/2020 and UIDP/04539/2020 (CIBB), SFRH/BD/109017/2015 (PhD Fellowship) and PTDC/SAU-NUT/31712/2017, as well as by COMPETE-FEDER funds (POCI-01-0145-FEDER-007440 and POCI-01-0145-FEDER-031712). BB juice phytochemical analyses received financial support from PT national funds (FCT/MCTES, Fundação para a Ciência e Tecnologia and Ministério da Ciência, Tecnologia e Ensino Superior) through Grant UIDB/50006/2020 and by Programa de Cooperación Interreg V-A España-Portugal (POCTEP) 2014-2020 (project 0377_IBERPHENOL_6_E). J.S.T. is a CNC assistant researcher, contracted under the CEEC program (CEECIND/04400/2017). NMR data was collected at the UC-NMR facility, which is supported in part by the FEDER-European Regional Development Fund through the COMPETE Programme (Operational Programme for Competitiveness) and by National Funds through FCT-Fundação para a Ciência e a Tecnologia (Portuguese Foundation for Science and Technology) through grants REEQ/481/QUU/2006, RECI/QEQ-QFI/0168/2012, CENTRO-07-CT62-FEDER-002012, and Rede Nacional de Ressonância Magnética Nuclear (RNRMN).

Conflicts of Interest: The authors declare no conflict of interest. 


\section{References}

1. Caretto, A.; Lagattolla, V. Non-Communicable Diseases and Adherence to Mediterranean Diet. Endocr. Metab. Immune Disord. Drug Targets 2015, 15, 10-17. [CrossRef] [PubMed]

2. Hyseni, L.; Atkinson, M.; Bromley, H.; Orton, L.; Lloyd-Williams, F.; McGill, R.; Capewell, S. The effects of policy actions to improve population dietary patterns and prevent diet-related non-communicable diseases: Scoping review. Eur. J. Clin. Nutr. 2016, 71, 694-711. [CrossRef] [PubMed]

3. Azzini, E.; Giacometti, J.; Russo, G.L. Antioxidant Phytochemicals at the Pharma-Nutrition Interface. Oxidative Med. Cell. Longev. 2017, 2017, 1-3. [CrossRef] [PubMed]

4. Ma, L.; Sun, Z.; Zeng, Y.; Luo, M.; Yang, J. Molecular Mechanism and Health Role of Functional Ingredients in Blueberry for Chronic Disease in Human Beings. Int. J. Mol. Sci. 2018, 19, 2785. [CrossRef]

5. Shukitt-Hale, B. Blueberries and Neuronal Aging. Gerontology 2012, 58, 518-523. [CrossRef]

6. Michalska, A.; Łysiak, G.P. Bioactive Compounds of Blueberries: Post-Harvest Factors Influencing the Nutritional Value of Products. Int. J. Mol. Sci. 2015, 16, 18642-18663. [CrossRef]

7. Miller, K.; Feucht, W.; Schmid, M. Bioactive Compounds of Strawberry and Blueberry and Their Potential Health Effects Based on Human Intervention Studies: A Brief Overview. Nutrients 2019, 11, 1510. [CrossRef]

8. Manach, C.; Williamson, G.; Morand, C.; Scalbert, A.; Rémésy, C. Bioavailability and bioefficacy of polyphenols in humans. I. Review of 97 bioavailability studies. Am. J. Clin. Nutr. 2005, 81, 230S-242S. [CrossRef]

9. Thilakarathna, S.H.; Rupasinghe, H.V. Flavonoid Bioavailability and Attempts for Bioavailability Enhancement. Nutrients 2013, 5, 3367-3387. [CrossRef]

10. Wu, B.; Kulkarni, K.; Basu, S.; Zhang, S.; Hu, M. First-Pass Metabolism via UDP-Glucuronosyltransferase: A Barrier to Oral Bioavailability of Phenolics. J. Pharm. Sci. 2011, 100, 3655-3681. [CrossRef]

11. Chang, S.K.; Alasalvar, C.; Shahidi, F. Superfruits: Phytochemicals, antioxidant efficacies, and health effects-A comprehensive review. Crit. Rev. Food Sci. Nutr. 2018, 59, 1580-1604. [CrossRef] [PubMed]

12. Faria, A.; Oliveira, J.; Neves, P.; Gameiro, P.; Santos-Buelga, C.; De Freitas, V.; Mateus, N. Antioxidant Properties of Prepared Blueberry (Vaccinium myrtillus) Extracts. J. Agric. Food Chem. 2005, 53, 6896-6902. [CrossRef] [PubMed]

13. Kalt, W.; Cassidy, A.; Howard, L.R.; Krikorian, R.; Stull, A.J.; Tremblay, F.; Zamora-Ros, R. Recent Research on the Health Benefits of Blueberries and Their Anthocyanins. Adv. Nutr. 2019, 11, 224-236. [CrossRef] [PubMed]

14. Han, Y.-K.; Park, S.W. Edible berries: Bioactive components and their effect on human health. Nutrients 2014, 30, 134-144. [CrossRef]

15. Kim, H.; Ramirez, C.N.; Su, Z.-Y.; Kong, A.-N. Epigenetic modifications of triterpenoid ursolic acid in activating Nrf2 and blocking cellular transformation of mouse epidermal cells. J. Nutr. Biochem. 2016, 33, 54-62. [CrossRef] [PubMed]

16. Li, Z.; Zhang, H.; Li, Y.; Chen, H.; Wang, C.; Wong, V.K.W.; Jiang, Z.-H.; Zhang, W. Phytotherapy using blueberry leaf polyphenols to alleviate non-alcoholic fatty liver disease through improving mitochondrial function and oxidative defense. Phytomedicine 2020, 69, 153209. [CrossRef] [PubMed]

17. Schmidt, H.H.; Stocker, R.; Vollbracht, C.; Paulsen, G.; Riley, D.; Daiber, A.; Cuadrado, A. Antioxidants in Translational Medicine. Antioxid. Redox Signal. 2015, 23, 1130-1143. [CrossRef] [PubMed]

18. Van Breda, S.G.; Briedé, J.J.; De Kok, T.M. Improved Preventive Effects of Combined Bioactive Compounds Present in Different Blueberry Varieties as Compared to Single Phytochemicals. Nutrients 2018, 11, 61. [CrossRef]

19. Aranaz, P.; Romo-Hualde, A.; Zabala, M.; Navarro-Herrera, D.; De Galarreta, M.R.; Gil, A.G.; Martínez, J.A.; Milagro, F.I.; González-Navarro, C.J. Freeze-dried strawberry and blueberry attenuates diet-induced obesity and insulin resistance in rats by inhibiting adipogenesis and lipogenesis. Food Funct. 2017, 8, 3999-4013. [CrossRef]

20. Eladwy, R.A.; Mantawy, E.M.; El-Bakly, W.M.; Fares, M.; Ramadan, L.A.; Azab, S.S. Mechanistic insights to the cardioprotective effect of blueberry nutraceutical extract in isoprenaline-induced cardiac hypertrophy. Phytomedicine 2018, 51, 84-93. [CrossRef]

21. Jiao, X.; Wang, Y.; Lin, Y.; Lang, Y.; Li, E.; Zhang, X.; Zhang, Q.; Feng, Y.; Meng, X.; Li, B. Blueberry polyphenols extract as a potential prebiotic with anti-obesity effects on C57BL/6 J mice by modulating the gut microbiota. J. Nutr. Biochem. 2019, 64, 88-100. [CrossRef] [PubMed] 
22. Ren, T.; Zhu, L.; Shen, Y.; Mou, Q.; Lin, T.; Feng, H. Protection of hepatocyte mitochondrial function by blueberry juice and probiotics via SIRT1 regulation in non-alcoholic fatty liver disease. Food Funct. 2019, 10, 1540-1551. [CrossRef] [PubMed]

23. Seymour, E.M.; Tanone, I.I.; Urcuyo-Llanes, D.E.; Lewis, S.K.; Kirakosyan, A.; Kondoleon, M.G.; Kaufman, P.B.; Bolling, S.F. Blueberry Intake Alters Skeletal Muscle and Adipose Tissue Peroxisome Proliferator-Activated Receptor Activity and Reduces Insulin Resistance in Obese Rats. J. Med. Food 2011, 14, 1511-1518. [CrossRef] [PubMed]

24. Vendrame, S.; Daugherty, A.; Kristo, A.S.; Klimis-Zacas, D. Wild blueberry (Vaccinium angustifolium)-enriched diet improves dyslipidaemia and modulates the expression of genes related to lipid metabolism in obese Zucker rats. Br. J. Nutr. 2013, 111, 194-200. [CrossRef] [PubMed]

25. Wang, Z.; Pang, W.; He, C.; Li, Y.; Jiang, Y.; Guo, C. Blueberry Anthocyanin-Enriched Extracts Attenuate Fine Particulate Matter $\left(\mathrm{PM}_{2.5}\right)$-Induced Cardiovascular Dysfunction. J. Agric. Food Chem. 2016, 65, 87-94. [CrossRef] [PubMed]

26. Curtis, P.J.; Van Der Velpen, V.; Berends, L.; Jennings, A.; Feelisch, M.; Umpleby, A.M.; Evans, M.; O Fernandez, B.; Meiss, M.S.; Minnion, M.; et al. Blueberries improve biomarkers of cardiometabolic function in participants with metabolic syndrome-Results from a 6-month, double-blind, randomized controlled trial. Am. J. Clin. Nutr. 2019, 109, 1535-1545. [CrossRef] [PubMed]

27. Rebello, C.J.; Burton, J.H.; Heiman, M.; Greenway, F.L. Gastrointestinal microbiome modulator improves glucose tolerance in overweight and obese subjects: A randomized controlled pilot trial. J. Diabetes Complicat. 2015, 29, 1272-1276. [CrossRef]

28. Riso, P.; Klimis-Zacas, D.; Del Bo', C.; Martini, D.; Campolo, J.; Vendrame, S.; Møller, P.; Loft, S.; De Maria, R.; Porrini, M. Effect of a wild blueberry (Vaccinium angustifolium) drink intervention on markers of oxidative stress, inflammation and endothelial function in humans with cardiovascular risk factors. Eur. J. Nutr. 2012, 52, 949-961. [CrossRef]

29. Stote, K.S.; Sweeney, M.I.; Kean, T.; Baer, D.J.; Novotny, J.A.; Shakerley, N.L.; Chandrasekaran, A.; Carrico, P.M.; Melendez, J.A.; Gottschall-Pass, K.T. The effects of 100\% wild blueberry (Vaccinium angustifolium) juice consumption on cardiometablic biomarkers: A randomized, placebo-controlled, crossover trial in adults with increased risk for type 2 diabetes. BMC Nutr. 2017, 3, 1-11. [CrossRef]

30. Stull, A.J.; Cash, K.C.; Champagne, C.M.; Gupta, A.K.; Boston, R.; Beyl, R.A.; Johnson, W.D.; Cefalu, W.T. Blueberries Improve Endothelial Function, but Not Blood Pressure, in Adults with Metabolic Syndrome: A Randomized, Double-Blind, Placebo-Controlled Clinical Trial. Nutrients 2015, 7, 4107-4123. [CrossRef]

31. Guglielmetti, S.; Fracassetti, D.; Taverniti, V.; Del Bo', C.; Vendrame, S.; Klimis-Zacas, D.; Arioli, S.; Riso, P.; Porrini, M. Differential Modulation of Human Intestinal Bifidobacterium Populations after Consumption of a Wild Blueberry (Vaccinium angustifolium) Drink. J. Agric. Food Chem. 2013, 61, 8134-8140. [CrossRef] [PubMed]

32. Istek, N.; Gurbuz, O. Investigation of the impact of blueberries on metabolic factors influencing health. J. Funct. Foods 2017, 38, 298-307. [CrossRef]

33. Kay, C.D.; Holub, B.J. The effect of wild blueberry (Vaccinium angustifolium) consumption on postprandial serum antioxidant status in human subjects. Br. J. Nutr. 2002, 88, 389-397. [CrossRef] [PubMed]

34. Mateos, A.M.R.; Rendeiro, C.; Bergillos-Meca, T.; Tabatabaee, S.; George, T.W.; Heiss, C.; Spencer, J.P. Intake and time dependence of blueberry flavonoid-induced improvements in vascular function: A randomized, controlled, double-blind, crossover intervention study with mechanistic insights into biological activity. Am. J. Clin. Nutr. 2013, 98, 1179-1191. [CrossRef] [PubMed]

35. Stote, K.S.; Corkum, A.; Sweeney-Nixon, M.; Shakerley, N.; Kean, T.; Gottschall-Pass, K. Postprandial Effects of Blueberry (Vaccinium angustifolium) Consumption on Glucose Metabolism, Gastrointestinal Hormone Response, and Perceived Appetite in Healthy Adults: A Randomized, Placebo-Controlled Crossover Trial. Nutrients 2019, 11, 202. [CrossRef] [PubMed]

36. Del Bo' , C.; Riso, P.; Campolo, J.; Møller, P.; Loft, S.; Klimis-Zacas, D.; Brambilla, A.; Rizzolo, A.; Porrini, M. A single portion of blueberry (Vaccinium corymbosum L.) improves protection against DNA damage but not vascular function in healthy male volunteers. Nutr. Res. 2013, 33, 220-227. [CrossRef]

37. Nyberg, S.; Gerring, E.; Gjellan, S.; Vergara, M.; Lindström, T.; Nystrom, F.H. Effects of exercise with or without blueberries in the diet on cardio-metabolic risk factors: An exploratory pilot study in healthy subjects. Upsala J. Med. Sci. 2013, 118, 247-255. [CrossRef] 
38. Warner, E.F.; Zhang, Q.; Raheem, K.S.; O'Hagan, D.; O'Connell, M.A.; Kay, C.D. Common Phenolic Metabolites of Flavonoids, but Not Their Unmetabolized Precursors, Reduce the Secretion of Vascular Cellular Adhesion Molecules by Human Endothelial Cells. J. Nutr. 2016, 146, 465-473. [CrossRef]

39. Rodriguez-Mateos, A.; Del Pino-García, R.; George, T.W.; Vidal-Diez, A.; Heiss, C.; Spencer, J.P.E. Impact of processing on the bioavailability and vascular effects of blueberry (poly)phenols. Mol. Nutr. Food Res. 2014, 58, 1952-1961. [CrossRef]

40. Barfoot, K.L.; May, G.; Lamport, D.J.; Ricketts, J.; Riddell, P.M.; Williams, C.M. The effects of acute wild blueberry supplementation on the cognition of 7-10-year-old schoolchildren. Eur. J. Nutr. 2019, 58, 2911-2920. [CrossRef]

41. McAnulty, L.S.; Collier, S.R.; Landram, M.J.; Whittaker, D.S.; Isaacs, S.E.; Klemka, J.M.; Cheek, S.L.; Arms, J.C.; McAnulty, S.R. Six weeks daily ingestion of whole blueberry powder increases natural killer cell counts and reduces arterial stiffness in sedentary males and females. Nutr. Res. 2014, 34, 577-584. [CrossRef] [PubMed]

42. Sengupta, P. The Laboratory Rat: Relating Its Age With Human's. Int. J. Prev. Med. 2013, 4, 624-630. [PubMed]

43. Adams, L.S.; Phung, S.; Yee, N.; Seeram, N.P.; Li, L.; Chen, S. Blueberry Phytochemicals Inhibit Growth and Metastatic Potential of MDA-MB-231 Breast Cancer Cells through Modulation of the Phosphatidylinositol 3-Kinase Pathway. Cancer Res. 2010, 70, 3594-3605. [CrossRef] [PubMed]

44. Reagan-Shaw, S.; Nihal, M.; Ahmad, N. Dose translation from animal to human studies revisited. FASEB J. 2007, 22, 659-661. [CrossRef]

45. Reque, P.M.; Steffens, R.S.; Jablonski, A.; Flores, S.H.; Rios, A.D.O.; De Jong, E.V. Cold storage of blueberry (Vaccinium spp.) fruits and juice: Anthocyanin stability and antioxidant activity. J. Food Compos. Anal. 2014, 33, 111-116. [CrossRef]

46. Kilkenny, C.; Browne, W.; Cuthill, I.C.; Emerson, M.; Altman, D.G. Animal research: Reporting in vivo experiments: The ARRIVE guidelines. Br. J. Pharmacol. 2010, 160, 1577-1579. [CrossRef]

47. Nunes, S.; Alves, A.; Preguiça, I.; Barbosa, A.; Vieira, P.; Mendes, F.; Martins, D.; Viana, S.D.; Reis, F. Crescent-Like Lesions as an Early Signature of Nephropathy in a Rat Model of Prediabetes Induced by a Hypercaloric Diet. Nutrients 2020, 12, 881. [CrossRef]

48. Conde, S.V.; Da Silva, T.N.; Gonzalez, C.; Carmo, M.M.; Monterio, E.C.; Guarino, M.P. Chronic caffeine intake decreases circulating catecholamines and prevents diet-induced insulin resistance and hypertension in rats. Br. J. Nutr. 2011, 107, 86-95. [CrossRef]

49. Ghezzi, A.C.; Cambri, L.T.; Botezelli, J.D.; Ribeiro, C.; Dalia, R.A.; De Mello, M.A.R. Metabolic syndrome markers in wistar rats of different ages. Diabetol. Metab. Syndr. 2012, 4, 16. [CrossRef]

50. Burgeiro, A.; Cerqueira, M.G.; Varela-Rodriguez, B.; Nunes, S.; Neto, P.; Pereira, F.C.; Reis, F.; Carvalho, R.A. Glucose and Lipid Dysmetabolism in a Rat Model of Prediabetes Induced by a High-Sucrose Diet. Nutrients 2017, 9, 638. [CrossRef]

51. Nunes, S.; Soares, E.; Fernandes, J.C.; Viana, S.D.; Carvalho, E.; Pereira, F.C.; Reis, F. Early cardiac changes in a rat model of prediabetes: Brain natriuretic peptide overexpression seems to be the best marker. Cardiovasc. Diabetol. 2013, 12, 44. [CrossRef] [PubMed]

52. Benzie, I.F.F.; Strain, J.J. The ferric reducing ability of plasma (FRAP) as a measure of "antioxidant power": The FRAP assay. Anal. Biochem. 1996, 239, 70-76. [CrossRef] [PubMed]

53. Gião, M.S.; González-Sanjosé, M.L.; Rivero-Pérez, M.D.; I Pereira, C.; E Pintado, M.; Malcata, F.X. Infusions of Portuguese medicinal plants: Dependence of final antioxidant capacity and phenol content on extraction features. J. Sci. Food Agric. 2007, 87, 2638-2647. [CrossRef] [PubMed]

54. Wishart, D.S.; Tzur, D.; Knox, C.; Eisner, R.; Guo, A.C.; Young, N.; Cheng, D.; Jewell, K.; Arndt, D.; Sawhney, S.; et al. HMDB: The Human Metabolome Database. Nucleic Acids Res. 2007, 35, D521-D526. [CrossRef]

55. Cloarec, O.; Dumas, M.-E.; Craig, A.; Barton, R.H.; Trygg, J.; Hudson, J.; Blancher, C.; Gauguier, D.; Lindon, J.C.; Holmes, A.E.; et al. Statistical Total Correlation Spectroscopy: An Exploratory Approach for Latent Biomarker Identification from Metabolic1H NMR Data Sets. Anal. Chem. 2005, 77, 1282-1289. [CrossRef] [PubMed]

56. Sumner, L.W.; Amberg, A.; Barrett, D.; Beale, M.H.; Beger, R.; Daykin, C.A.; Fan, T.W.-M.; Fiehn, O.; Goodacre, R.; Griffin, J.; et al. Proposed minimum reporting standards for chemical analysis Chemical Analysis Working Group (CAWG) Metabolomics Standards Initiative (MSI). Metabolomics 2007, 3, $211-221$. [CrossRef] 
57. Savorani, F.; Tomasi, G.; Engelsen, S.B. icoshift: A versatile tool for the rapid alignment of 1D NMR spectra. J. Magn. Reson. 2010, 202, 190-202. [CrossRef]

58. Triba, M.N.; Le Moyec, L.; Amathieu, R.; Goossens, C.; Bouchemal, N.; Nahon, P.; Rutledge, D.N.; Savarin, P. PLS/OPLS models in metabolomics: The impact of permutation of dataset rows on the K-fold cross-validation quality parameters. Mol. BioSyst. 2015, 11, 13-19. [CrossRef]

59. Reis, F.; Madureira, A.R.; Nunes, S.; Campos, D.A.; Fernandes, J.C.; Marques, C.; Zuzarte, M.; Gullon, B.; Rodríguez-Alcalá, L.M.; Calhau, C.; et al. Safety profile of solid lipid nanoparticles loaded with rosmarinic acid for oral use: In vitro and animal approaches. Int. J. Nanomed. 2016, 11, 3621-3640. [CrossRef]

60. Kumar, A.; Lawrence, J.C.; Jung, D.Y.; Ko, H.J.; Keller, S.R.; Kim, J.K.; Magnuson, M.A.; Harris, T.E. Fat Cell-Specific Ablation of Rictor in Mice Impairs Insulin-Regulated Fat Cell and Whole-Body Glucose and Lipid Metabolism. Diabetes 2010, 59, 1397-1406. [CrossRef]

61. Rolo, A.P.; Oliveira, P.J.; Moreno, A.J.; Palmeira, C.M. Bile acids affect liver mitochondrial bioenergetics: Possible relevance for cholestasis therapy. Toxicol. Sci. 2000, 57, 177-185. [CrossRef] [PubMed]

62. Varela, A.T.; Simões, A.M.; Teodoro, J.S.; Duarte, F.V.; Gomes, A.P.; Palmeira, C.M.; Rolo, A.P. Indirubin-3'-oxime prevents hepatic I/R damage by inhibiting GSK-3 $\beta$ and mitochondrial permeability transition. Mitochondrion 2010, 10, 456-463. [CrossRef] [PubMed]

63. Gornall, A.G.; Bardawill, C.J.; David, M.M. Determination of serum proteins by means of the biuret reaction. J. Biol. Chem. 1949, 177, 751-766. [PubMed]

64. Teodoro, J.S.; Duarte, F.V.; Gomes, A.P.; Varela, A.T.; Peixoto, F.; Rolo, A.P.; Palmeira, C.M. Berberine reverts hepatic mitochondrial dysfunction in high-fat fed rats: A possible role for SirT3 activation. Mitochondrion 2013, 13, 637-646. [CrossRef] [PubMed]

65. DeFuria, J.; Bennett, G.; Strissel, K.J.; Perfield, J.W.; Milbury, P.E.; Greenberg, A.S.; Obin, M.S. Dietary Blueberry Attenuates Whole-Body Insulin Resistance in High Fat-Fed Mice by Reducing Adipocyte Death and Its Inflammatory Sequelae. J. Nutr. 2009, 139, 1510-1516. [CrossRef] [PubMed]

66. Ebenezer, P.J.; Wilson, C.B.; Wilson, L.D.; Nair, A.R.; Francis, J. The Anti-Inflammatory Effects of Blueberries in an Animal Model of Post-Traumatic Stress Disorder (PTSD). PLoS ONE 2016, 11, e0160923. [CrossRef]

67. Barbian, M.E.; Buckle, R.; Denning, P.W.; Patel, R.M. To start or not: Factors to consider when implementing routine probiotic use in the NICU. Early Hum. Dev. 2019, 135, 66-71. [CrossRef]

68. Gulati, O.P.; Ottaway, P.B. Legislation relating to nutraceuticals in the European Union with a particular focus on botanical-sourced products. Toxicology 2006, 221, 75-87. [CrossRef]

69. Marra, M.V.; Bailey, R.L. Position of the Academy of Nutrition and Dietetics: Micronutrient Supplementation. J. Acad. Nutr. Diet. 2018, 118, 2162-2173. [CrossRef]

70. Dulebohn, R.V.; Yi, W.; Srivastava, A.; Akoh, C.C.; Krewer, G.; Fischer, J.G. Effects of Blueberry (Vaccinium ashei) on DNA Damage, Lipid Peroxidation, and Phase II Enzyme Activities in Rats. J. Agric. Food Chem. 2008, 56, 11700-11706. [CrossRef]

71. Rendeiro, C.; Vauzour, D.; Kean, R.J.; Butler, L.T.; Rattray, M.; Spencer, J.P.E.; Williams, C.M. Blueberry supplementation induces spatial memory improvements and region-specific regulation of hippocampal BDNF mRNA expression in young rats. Psychopharmacology 2012, 223, 319-330. [CrossRef] [PubMed]

72. Grace, M.H.; Ribnicky, D.M.; Kuhn, P.; Poulev, A.; Logendra, S.; Yousef, G.G.; Raskin, I.; Lila, M.A. Hypoglycemic activity of a novel anthocyanin-rich formulation from lowbush blueberry, Vaccinium angustifolium Aiton. Phytomedicine 2009, 16, 406-415. [CrossRef] [PubMed]

73. Khanal, R.C.; Howard, L.R.; Wilkes, S.E.; Rogers, T.J.; Prior, R.L. Effect of Dietary Blueberry Pomace on Selected Metabolic Factors Associated with High Fructose Feeding in Growing Sprague-Dawley Rats. J. Med. Food 2012, 15, 802-810. [CrossRef] [PubMed]

74. Martineau, L.C.; Couture, A.; Spoor, D.; Benhaddou-Andaloussi, A.; Harris, C.; Meddah, B.; LeDuc, C.; Burt, A.; Vuong, T.; Le, P.M.; et al. Anti-diabetic properties of the Canadian lowbush blueberry Vaccinium angustifolium Ait. Phytomedicine 2006, 13, 612-623. [CrossRef] [PubMed]

75. Stull, A.J.; Cash, K.C.; Johnson, W.D.; Champagne, C.M.; Cefalu, W.T. Bioactives in Blueberries Improve Insulin Sensitivity in Obese, Insulin-Resistant Men and Women. J. Nutr. 2010, 140, 1764-1768. [CrossRef] [PubMed]

76. Vuong, T.; Benhaddou-Andaloussi, A.; Brault, A.; Harbilas, D.; Martineau, L.C.; Vallerand, D.; Ramassamy, C.; Matar, C.; Haddad, P.S. Antiobesity and antidiabetic effects of biotransformed blueberry juice in KKAy mice. Int. J. Obes. 2009, 33, 1166-1173. [CrossRef] [PubMed] 
77. Vuong, T.; Martineau, L.C.; Ramassamy, C.; Matar, C.; Haddad, P.S. Fermented Canadian lowbush blueberry juice stimulates glucose uptake and AMP-activated protein kinase in insulin-sensitive cultured muscle cells and adipocytes. Can. J. Physiol. Pharmacol. 2007, 85, 956-965. [CrossRef]

78. Guo, J.; Han, X.; Tan, H.; Huang, W.; You, Y.; Zhan, J. Blueberry Extract Improves Obesity through Regulation of the Gut Microbiota and Bile Acids via Pathways Involving FXR and TGR5. iScience 2019, 19, 676-690. [CrossRef]

79. Prior, R.L.; Wilkes, S.E.; Rogers, T.R.; Khanal, R.C.; Wu, X.; Howard, L.R. Purified Blueberry Anthocyanins and Blueberry Juice Alter Development of Obesity in Mice Fed an Obesogenic High-Fat Diett. J. Agric. Food Chem. 2010, 58, 3970-3976. [CrossRef]

80. Wankhade, U.D.; Zhong, Y.; Lazarenko, O.P.; Chintapalli, S.V.; Piccolo, B.D.; Chen, J.; Shankar, K. Sex-Specific Changes in Gut Microbiome Composition following Blueberry Consumption in C57BL/6J Mice. Nutrients 2019, 11, 313. [CrossRef]

81. Lacombe, A.; Li, R.W.; Klimis-Zacas, D.; Kristo, A.S.; Tadepalli, S.; Krauss, E.; Young, R.; Wu, V.C.H. Lowbush Wild Blueberries have the Potential to Modify Gut Microbiota and Xenobiotic Metabolism in the Rat Colon. PLoS ONE 2013, 8, e67497. [CrossRef] [PubMed]

82. Lee, S.; I Keirsey, K.; Kirkland, R.; I Grunewald, Z.; Fischer, J.G.; De La Serre, C.B. Blueberry Supplementation Influences the Gut Microbiota, Inflammation, and Insulin Resistance in High-Fat-Diet-Fed Rats. J. Nutr. 2018, 148, 209-219. [CrossRef] [PubMed]

83. Paturi, G.; Mandimika, T.; Butts, C.A.; Zhu, S.; Roy, N.C.; McNabb, W.C.; Ansell, J. Influence of dietary blueberry and broccoli on cecal microbiota activity and colon morphology in mdr1a-/- mice, a model of inflammatory bowel diseases. Nutrients 2012, 28, 324-330. [CrossRef] [PubMed]

84. De Vadder, F.; Kovatcheva-Datchary, P.; Zitoun, C.; Duchampt, A.; Bäckhed, F.; Mithieux, G. Microbiota-Produced Succinate Improves Glucose Homeostasis via Intestinal Gluconeogenesis. Cell Metab. 2016, 24, 151-157. [CrossRef]

85. De Vadder, F.; Mithieux, G. Gut-brain signaling in energy homeostasis: The unexpected role of microbiota-derived succinate. J. Endocrinol. 2018, 236, R105-R108. [CrossRef]

86. Mills, E.L.; Pierce, K.A.; Jedrychowski, M.P.; Garrity, R.; Winther, S.; Vidoni, S.; Yoneshiro, T.; Spinelli, J.B.; Lu, G.Z.; Kazak, L.; et al. Accumulation of succinate controls activation of adipose tissue thermogenesis. Nat. Cell Biol. 2018, 560, 102-106. [CrossRef]

87. Haraguchi, T.; Kayashima, T.; Okazaki, Y.; Inoue, J.; Mineo, S.; Matsubara, K.; Sakaguchi, E.; Yanaka, N.; Kato, N. Cecal Succinate Elevated by Some Dietary Polyphenols May Inhibit Colon Cancer Cell Proliferation and Angiogenesis. J. Agric. Food Chem. 2014, 62, 5589-5594. [CrossRef]

88. Johnson, J.S.; Spakowicz, D.; Hong, B.-Y.; Petersen, L.M.; Demkowicz, P.; Chen, L.; Leopold, S.R.; Hanson, B.M.; Agresta, H.O.; Gerstein, M.; et al. Evaluation of $16 \mathrm{~S}$ rRNA gene sequencing for species and strain-level microbiome analysis. Nat. Commun. 2019, 10,1-11. [CrossRef]

89. Adam, C.L.; Gratz, S.W.; Peinado, D.I.; Thomson, L.M.; Garden, K.E.; Williams, P.A.; Richardson, A.J.; Ross, A.W. Effects of Dietary Fibre (Pectin) and/or Increased Protein (Casein or Pea) on Satiety, Body Weight, Adiposity and Caecal Fermentation in High Fat Diet-Induced Obese Rats. PLoS ONE 2016, 11, e0155871. [CrossRef]

90. Fernández-Veledo, S.; Vendrell, J. Gut microbiota-derived succinate: Friend or foe in human metabolic diseases? Rev. Endocr. Metab. Disord. 2019, 20, 439-447. [CrossRef]

91. Louis, P.; Flint, H.J. Formation of propionate and butyrate by the human colonic microbiota. Environ. Microbiol. 2016, 19, 29-41. [CrossRef] [PubMed]

92. Kim, M.; Na, H.; Kasai, H.; Kawai, K.; Li, Y.-S.; Yang, M. Comparison of Blueberry (Vaccinium spp.) and Vitamin C via Antioxidative and Epigenetic Effects in Human. J. Cancer Prev. 2017, 22, 174-181. [CrossRef] [PubMed]

93. Silva, S.; Costa, E.M.; Veiga, M.; Morais, R.M.; Calhau, C.; Pintado, M. Health promoting properties of blueberries: A review. Crit. Rev. Food Sci. Nutr. 2020, 60, 181-200. [CrossRef] [PubMed]

94. Xiao, T.; Guo, Z.; Sun, B.; Zhao, Y.-Q. Identification of Anthocyanins from Four Kinds of Berries and Their Inhibition Activity to $\alpha$-Glycosidase and Protein Tyrosine Phosphatase 1B by HPLC-FT-ICR MS/MS. J. Agric. Food Chem. 2017, 65, 6211-6221. [CrossRef] 
95. Basu, A.; Du, M.; Leyva, M.J.; Sanchez, K.; Betts, N.M.; Wu, M.; Aston, C.E.; Lyons, T.J. Blueberries Decrease Cardiovascular Risk Factors in Obese Men and Women with Metabolic Syndrome. J. Nutr. 2010, 140, 1582-1587. [CrossRef]

96. Giongo, L.; Bozza, E.; Caciagli, P.; Valente, E.; Pasquazzo, M.T.; Pedrolli, C.; Iorio, E.L.; Costa, A.J.L. Short-term blueberry intake enhances biological antioxidant potential and modulates inflammation markers in overweight and obese children. J. Berry Res. 2011, 1, 147-158. [CrossRef]

97. Locatelli, C.; Nardi, G.M.; anuário, A.F.; Freire, C.G.; Megiolaro, F.; Schneider, K.; Perazzoli, M.R.A.; Nascimento, S.R.D.; Gon, A.C.; Mariano, L.N.B.; et al. Anti-inflammatory activity of berry fruits in mice model of inflammation is based on oxidative stress modulation. Pharmacogn. Res. 2016, 8, 42-49. [CrossRef] [PubMed]

98. Fukao, T.; Mitchell, G.; Sass, J.O.; Hori, T.; Orii, K.; Aoyama, Y. Ketone body metabolism and its defects. J. Inherit. Metab. Dis. 2014, 37, 541-551. [CrossRef]

99. Newman, J.C.; Verdin, E. Ketone bodies as signaling metabolites. Trends Endocrinol. Metab. 2014, $25,42-52$. [CrossRef] [PubMed]

100. Bhagavan, N.; Ha, C.-E. Essentials of Medical Biochemistry: With Clinical Cases, 2nd ed.; Elsevier Science Publishing Co Inc./Academic Press: San Diego, CA, USA, 2015; p. 752.

101. De Oliveira, M.R.; Nabavi, S.M.; Manayi, A.; Daglia, M.; Hajheydari, Z. Resveratrol and the mitochondria: From triggering the intrinsic apoptotic pathway to inducing mitochondrial biogenesis, a mechanistic view. Biochim. Biophys. Acta Gen. Subj. 2016, 1860, 727-745. [CrossRef]

102. Grabacka, M.; Gawin, M.; Pierzchalska, M. Phytochemical Modulators of Mitochondria: The Search for Chemopreventive Agents and Supportive Therapeutics. Pharmaceuticals 2014, 7, 913-942. [CrossRef] [PubMed]

103. Chen, F.; Wang, P.; Zhu, Y.; Liu, X.; Hu, X.; Chen, F. The chemoprotection of a blueberry anthocyanin extract against the acrylamide-induced oxidative stress in mitochondria: Unequivocal evidence in mice liver. Food Funct. 2015, 6, 3006-3012. [CrossRef]

104. Giannini, E.G.; Testa, R.; Savarino, V. Liver enzyme alteration: A guide for clinicians. Can. Med. Assoc. J. 2005, 172, 367-379. [CrossRef] [PubMed]

105. Hall, P.; Cash, J. What is the Real Function of the Liver 'Function' Tests? Ulst. Med. J. 2012, 81, 30-36.

106. Lemasters, J.J.; Theruvath, T.P.; Zhong, Z.; Nieminen, A.-L. Mitochondrial calcium and the permeability transition in cell death. Biochim. Biophys. Acta (BBA)-Bioenerg. 2009, 1787, 1395-1401. [CrossRef]

107. Brookes, P.S. Mitochondrial H+ leak and ROS generation: An odd couple. Free. Radic. Biol. Med. 2005, 38, 12-23. [CrossRef]

108. Murphy, M.P.Slip and leak in mitochondrial oxidative phosphorylation. Biochim. Biophys. Acta (BBA)-Bioenerg. 1989, 977, 123-141. [CrossRef]

109. Brand, M.D.; Nicholls, D.G. Assessing mitochondrial dysfunction in cells. Biochem. J. 2011, 435, $297-312$. [CrossRef]

110. De Marchi, U.; Biasutto, L.; Garbisa, S.; Toninello, A.; Zoratti, M. Quercetin can act either as an inhibitor or an inducer of the mitochondrial permeability transition pore: A demonstration of the ambivalent redox character of polyphenols. Biochim. Biophys. Acta (BBA)-Bioenerg. 2009, 1787, 1425-1432. [CrossRef]

111. Ligeret, H.; Barthelemy, S.; Zini, R.; Tillement, J.-P.; Labidalle, S.; Morin, D. Effects of curcumin and curcumin derivatives on mitochondrial permeability transition pore. Free. Radic. Biol. Med. 2004, 36, 919-929. [CrossRef]

112. Zheng, J.; Ramirez, V.D. Inhibition of mitochondrial proton F0F1-ATPase/ATP synthase by polyphenolic phytochemicals. Br. J. Pharmacol. 2000, 130, 1115-1123. [CrossRef] [PubMed]

113. Trumbeckaitè, S.; Burdulis, D.; Raudonè, L.; Liobikas, J.; Baniene, R.; Janulis, V. Direct Effects of Vaccinium myrtillus L. Fruit Extracts on Rat Heart Mitochondrial Functions. Phytother. Res. 2012, 27, 499-506. [CrossRef]

114. Black, P.N.; Sandoval, A.; Arias-Barrau, E.; DiRusso, C.C. Targeting the Fatty Acid Transport Proteins (FATP) to Understand the Mechanisms Linking Fatty Acid Transport to Metabolism. Immunol. Endocr. Metab. Agents Med. Chem. 2009, 9, 11-17. [CrossRef] [PubMed]

115. Grabacka, M.; Pierzchalska, M.; Dean, M.; Reiss, K. Regulation of Ketone Body Metabolism and the Role of PPAR $\alpha$. Int. J. Mol. Sci. 2016, 17, 2093. [CrossRef] [PubMed]

116. Puchalska, P.; Crawford, P.A. Multi-dimensional Roles of Ketone Bodies in Fuel Metabolism, Signaling, and Therapeutics. Cell Metab. 2017, 25, 262-284. [CrossRef] [PubMed] 
117. Ren, T.; Zhu, J.; Zhu, L.; Cheng, M. The Combination of Blueberry Juice and Probiotics Ameliorate Non-Alcoholic Steatohepatitis (NASH) by Affecting SREBP-1c/PNPLA-3 Pathway via PPAR- $\alpha$. Nutrients 2017, 9, 198. [CrossRef] [PubMed]

118. Oosterveer, M.H.; Schoonjans, K. Hepatic glucose sensing and integrative pathways in the liver. Cell. Mol. Life Sci. 2014, 71, 1453-1467. [CrossRef]

119. Pusec, C.M.; De Jesus, A.; Khan, W.; Terry, A.R.; E Ludvik, A.; Xu, K.; Giancola, N.; Pervaiz, H.; Smith, E.D.; Ding, X.; et al. Hepatic HKDC1 Expression Contributes to Liver Metabolism. Endocrinology 2018, 160, 313-330. [CrossRef]

120. Peeters, A.; Baes, M. Role of PPAR $\alpha$ in Hepatic Carbohydrate Metabolism. PPAR Res. 2010, $2010,1-12$. [CrossRef]

121. Bondoc, F.Y.; Bao, Z.; Shu-Chen, C.; Gonzalez, F.J.; Wang, Y.; Yang, C.S.; Hong, J.-Y. Acetone catabolism by cytochrome P450 2E1: Studies with CYP2E1-null mice. Biochem. Pharmacol. 1999, 58, 461-463. [CrossRef]

122. Lee, S.S.T.; Buters, J.T.M.; Pineau, T.; Fernandez-Salguero, P.; Gonzalez, F.J. Role of CYP2E1 in the Hepatotoxicity of Acetaminophen. J. Biol. Chem. 1996, 271, 12063-12067. [CrossRef] [PubMed]

123. Tian, J.-L.; Liao, X.-J.; Wang, Y.; Si, X.; Shu, C.; Gong, E.-S.; Xie, X.; Ran, X.-L.; Li, B. Identification of Cyanidin-3-arabinoside Extracted from Blueberry as a Selective Protein Tyrosine Phosphatase 1B Inhibitor. J. Agric. Food Chem. 2019, 67, 13624-13634. [CrossRef] [PubMed]

124. Huang, W.; Fu, L.; Li, C.; Xu, L.; Zhang, L.; Zhang, W.-M. Quercetin, Hyperin, and Chlorogenic Acid Improve Endothelial Function by Antioxidant, Antiinflammatory, and ACE Inhibitory Effects. J. Food Sci. 2017, 82, 1239-1246. [CrossRef] [PubMed]

125. Rutledge, G.A.; Fisher, D.R.; Miller, M.G.; Kelly, M.E.; Bielinski, D.F.; Shukitt-Hale, B. The effects of blueberry and strawberry serum metabolites on age-related oxidative and inflammatory signaling in vitro. Food Funct. 2019, 10, 7707-7713. [CrossRef] [PubMed]

126. Webb, M.R.; Min, K.; Ebeler, S.E. DNA Intercalation, Topoisomerase I Inhibition, and Oxidative Reactions of Polyphenols. In Functional Food and Health; American Chemical Society: Washinhgton, DC, USA, 2008; Volume 993, pp. 320-334.

127. Russo, G.L.; Vastolo, V.; Ciccarelli, M.; Albano, L.; Macchia, P.E.; Ungaro, P. Dietary polyphenols and chromatin remodeling. Crit. Rev. Food Sci. Nutr. 2017, 57, 2589-2599. [CrossRef] [PubMed]

128. Gezer, C. Stress Response of Dietary Phytochemicals in a Hormetic Manner for Health and Longevity. In Gene Expression and Regulation in Mammalian Cells-Transcription Toward the Establishment of Novel Therapeutics; Fumiaki Uchiumi, I., Ed.; IntechOpen: London, UK, 2018; pp. 3-23. [CrossRef]

129. Calabrese, E.J.; Mattson, M.P. How does hormesis impact biology, toxicology, and medicine? Npj Aging Mech. Dis. 2017, 3, 1-8. [CrossRef]

130. Son, T.G.; Camandola, S.; Mattson, M.P. Hormetic Dietary Phytochemicals. Neuromol. Med. 2008, 10, $236-246$. [CrossRef]

131. Musci, R.V.; Hamilton, K.L.; Linden, M.A. Exercise-Induced Mitohormesis for the Maintenance of Skeletal Muscle and Healthspan Extension. Sports 2019, 7, 170. [CrossRef]

132. Palmeira, C.M.; Teodoro, J.S.; Amorim, J.A.; Steegborn, C.; Sinclair, D.A.; Rolo, A.P. Mitohormesis and metabolic health: The interplay between ROS, cAMP and sirtuins. Free. Radic. Biol. Med. 2019, 141, 483-491. [CrossRef]

133. Yi, H.-S.; Chang, J.Y.; Shong, M. The mitochondrial unfolded protein response and mitohormesis: A perspective on metabolic diseases. J. Mol. Endocrinol. 2018, 61, R91-R105. [CrossRef]

134. Yun, J.; Finkel, T. Mitohormesis. Cell Metab. 2014, 19, 757-766. [CrossRef] [PubMed]

135. Esparza-Moltó, P.B.; Nuevo-Tapioles, C.; Cuezva, J.M. Regulation of the H+-ATP synthase by IF1: A role in mitohormesis. Cell. Mol. Life Sci. 2017, 74, 2151-2166. [CrossRef] [PubMed]

136. Von Schulze, A.; McCoin, C.S.; Onyekere, C.; Allen, J.; Geiger, P.C.; Ii, G.W.D.; Morris, E.M.; Thyfault, J.P. Hepatic mitochondrial adaptations to physical activity: Impact of sexual dimorphism, PGC1 $\alpha$ and BNIP3-mediated mitophagy. J. Physiol. 2018, 596, 6157-6171. [CrossRef] [PubMed]

137. Liesa, M.; Shirihai, O. Mitochondrial Dynamics in the Regulation of Nutrient Utilization and Energy Expenditure. Cell Metab. 2013, 17, 491-506. [CrossRef] [PubMed]

138. Miller, V.; Villamena, F.A.; Volek, J.S. Nutritional Ketosis and Mitohormesis: Potential Implications for Mitochondrial Function and Human Health. J. Nutr. Metab. 2018, 2018, 1-27. [CrossRef] 
139. Lushchak, V.I. Dissection of the Hormetic Curve: Analysis of Components and Mechanisms. Dose-Response 2014, 12, 466-479. [CrossRef]

140. Egert, S.; Rimbach, G. Which Sources of Flavonoids: Complex Diets or Dietary Supplements? Adv. Nutr. 2011, 2, 8-14. [CrossRef]

141. Schmidt-Heck, W.; Wönne, E.C.; Hiller, T.; Menzel, U.; Koczan, D.; Damm, G.; Seehofer, D.; Knöspel, F.; Freyer, N.; Guthke, R.; et al. Global Transcriptional Response of Human Liver Cells to Ethanol Stress of Different Strength Reveals Hormetic Behavior. Alcohol. Clin. Exp. Res. 2017, 41, 883-894. [CrossRef]

142. Detampel, P.; Beck, M.; Krähenbühl, S.; Huwyler, J. Drug interaction potential of resveratrol. Drug Metab. Rev. 2012, 44, 253-265. [CrossRef]

143. Korobkova, E.A. Effect of Natural Polyphenols on CYP Metabolism: Implications for Diseases. Chem. Res. Toxicol. 2015, 28, 1359-1390. [CrossRef]

144. Mikstacka, R.; Gnojkowski, J.; Baer-Dubowska, W. Effect of natural phenols on the catalytic activity of cytochrome P450 2E. Acta Biochim. Pol. 2002, 49, 917-925. [CrossRef] [PubMed]

Publisher's Note: MDPI stays neutral with regard to jurisdictional claims in published maps and institutional affiliations.

(C) 2020 by the authors. Licensee MDPI, Basel, Switzerland. This article is an open access article distributed under the terms and conditions of the Creative Commons Attribution (CC BY) license (http://creativecommons.org/licenses/by/4.0/). 